\title{
Working
}

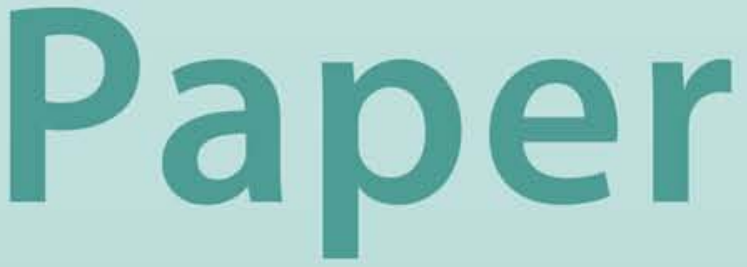


Managing Financial Crises: The Experience in East Asia

\author{
Jack Boorman, Timothy Lane, \\ Marianne Schulze-Ghattas, Aleš Bulír, \\ Atish R. Ghosh, Javier Hamann, \\ Alexandros Mourmouras, and Steven Phillips
}




\title{
IMF Working Paper
}

Policy Development and Review Department

\section{Managing Financial Crises: The Experience in East Asia}

Prepared by Jack Boorman, Timothy Lane, Marianne Schulze-Ghattas, Aleš Buliřr, Atish R. Ghosh, Javier Hamann, Alexandros Mourmouras, and Steven Phillips ${ }^{1}$

June 2000

\begin{abstract}
The views expressed in this Working Paper are those of the authors and do not necessarily represent those of the IMF or IMF policy. Working Papers describe research in progress by the authors and are published to elicit comments and to further debate.
\end{abstract}

The Asian financial crisis of 1997-98 was one of the most dramatic economic events of recent times, which raised many questions regarding the appropriate policy response to financial crises. This paper reviews the experience of this crisis, focusing on the overall strategy of crisis management and the way that strategy was implemented, including with regard to official and private financing, structural reforms, and monetary and fiscal policies.

JEL Classification Numbers:F3, F4

Keywords: East Asian financial crisis, IMF

Author's E-Mail Address: tlane@imf.org

\footnotetext{
${ }^{1}$ This paper was presented at the conference on Financial Crisis and the Role of the IMF held in Pittsburgh PA on November 19-20, 1999 and will be published in the Carnegie-Rochester Conference Series on Public Policy. The authors are grateful for helpful comments and suggestions provided by Stanley Fischer, Bennett McCallum, Thomas Willett, and numerous colleagues in the IMF. Expert research assistance was provided by Sibabrata Das and Patricia Gillett-Lorusso. The authors are solely responsible for any remaining errors.
} 


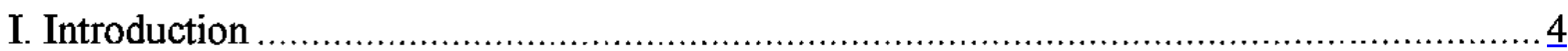

II. The Strategy of the Programs

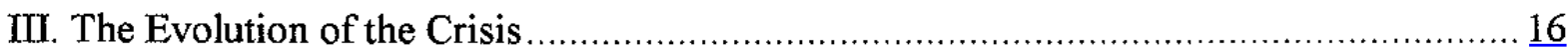

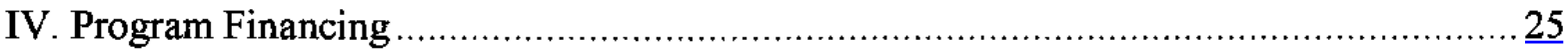

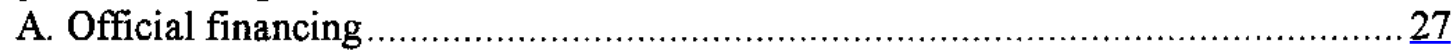

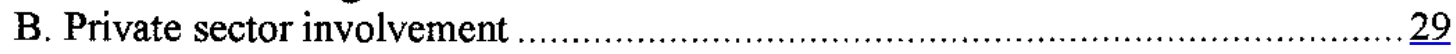

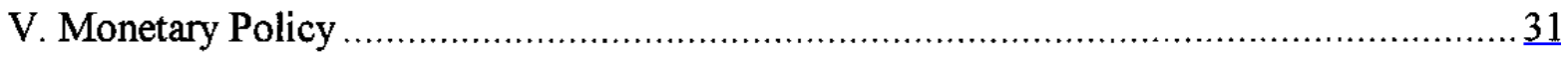

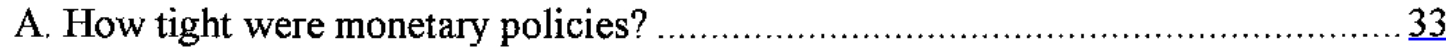

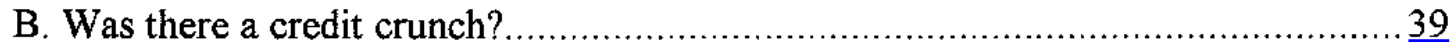

C. Was monetary tightening counterproductive? .............................................

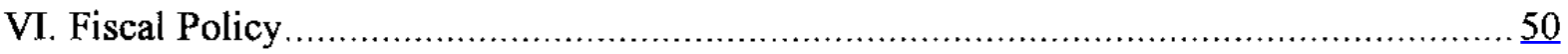

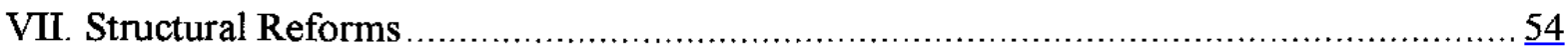

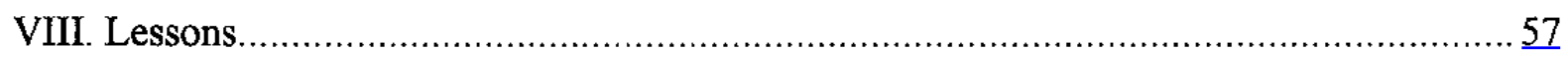

Boxes

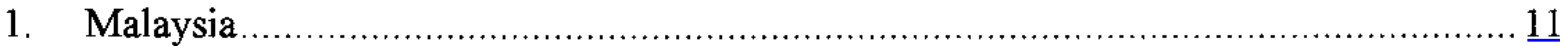

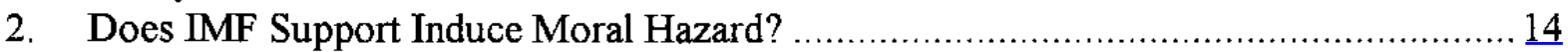

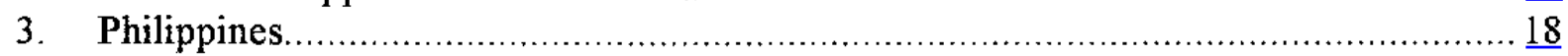

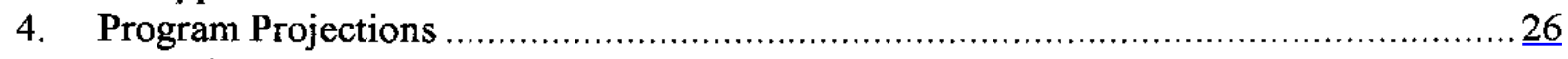

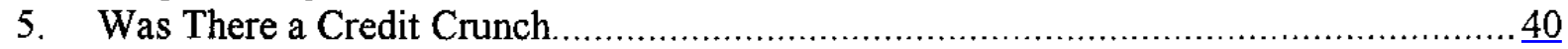

6. Episodic Evidence on the Interest Rate-Exchange Rate Relationship …....................43

7. Did High Interest Rates Contribute to Weakening of the Exchange Rate? .................... 48

Figures

1. Indonesia, Korea and Thailand: Sectoral Savings-Investment Balances ..................... $\underline{7}$

2. Indonesia, Korea, Malaysia, Philippines and Thailand: Nominal and Real Effective Exchange Rates, June 1997-June 1999 ........................................................

3. Indonesia, Korea, Malaysia, Philippines and Thailand: Indicators of Economic

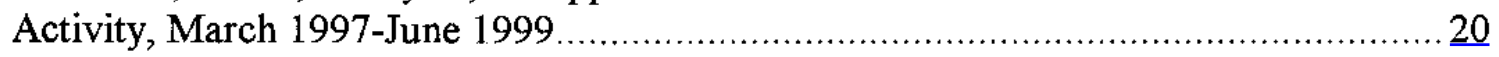

4. Indonesia, Korea, Malaysia, Philippines and Thailand: Contributions to

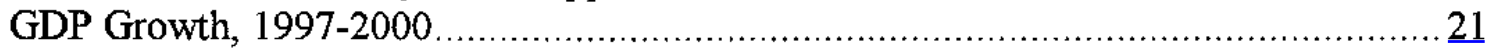

5. Indonesia, Korea, Malaysia, Philippines and Thailand: Net Capital Inflows, March 1997-June 1999 ....

6. Indonesia, Korea, Malaysia, Philippines and Thailand: Inflation January 1997-July 1999

7. Indonesia, Korea, Malaysia, Philippines and Thailand: Nominal and Estimated Real Interest Rates, January 1997-July 1999. 
8. Indonesia, Korea, Malaysia, Philippines and Thailand: Money and Domestic Credit

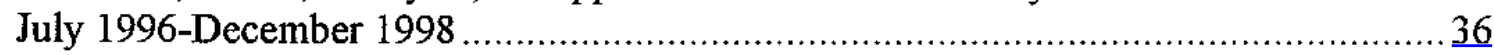

9. Indonesia, Korea, Malaysia, Philippines and Thailand: Money and Domestic Credit

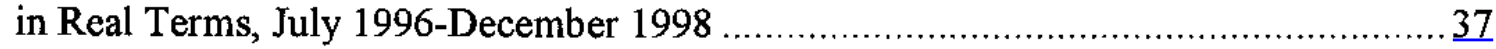

10. Interest Rates and Exchange Rates in Selected Asian Crisis Countries ....................... 45

11. Broad Money and Exchange Rates in Selected Asian Crisis Countries........................47

12. Indonesia, Korea, Malaysia, Philippines and Thailand: Central Government Balances, 1990-1999

Text Tables

1. Indonesia, Korea, and Thailand: Official Financing Packages ................................2. 28

2. Indonesia, Korea, and Thailand: Sources of Changes in the Fiscal

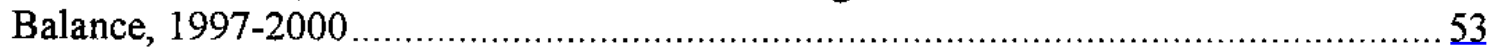

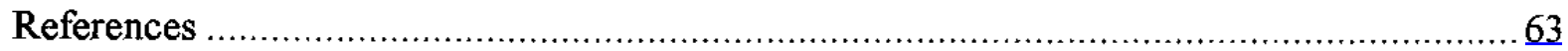




\section{INTRODUCTION}

The Asian financial crisis of 1997-98 was one of the most dramatic economic events of recent times. The countries affected, which had enjoyed a period of stability and rising living standards, saw their currencies plummet in value and their economies plunged into slumps that threw many of their citizens back into poverty. The crisis also ushered in a period of heightened volatility in global markets.

In most countries affected, markets began to stabilize around the middle of 1998, with interest rates declining to below pre-crisis levels and exchange rates beginning to rebound. Economic activity began to bottom out in the second half of 1998 and, by the fall of 1999 , was well on the way to recovery in most countries, particularly in Korea. Even in Indonesia, which had needed to tackle towering structural problems amid severe political and social unrest, recovery was under way, although it was slower to materialize and remains more uncertain.

The crisis has challenged many established views. The onset of the crisis took observers by surprise, occurring as it did in "tiger economies" whose macroeconomic policies had in most cases been seen as relatively sound. This has prompted the reexamination of theories of the genesis and evolution of crises. The persistence--indeed, for a time, intensification - of the crises after the initial policy responses in the context of IMFsupported programs has led to a reexamination of how crises should be managed. Various aspects of the experience have also given impetus to efforts to redesign the "global financial architecture. $^{\prime 2}$

This paper will examine the lessons of the Asian crisis for crisis management. It focuses primarily on the experience of Indonesia, Korea, and Thailand, which sought to deal with the crisis in the context of IMF-supported programs. However, for purposes of comparison, it will also consider the experience of two other countries: Malaysia, which faced similar market pressures without IMF support and, controversially, introduced capital controls to quell capital outflows; and the Philippines, where pre-crisis growth rates of real GDP were modest and short-term external exposure was smaller than in other countries in the region.

The paper's central focus will be on crisis management rather than on the origins of the crisis. ${ }^{3}$ It will also not focus primarily on reviewing the events in the countries affected,

${ }^{2}$ See for instance Eichengreen, 1999; and Rogoff, 1999.

${ }^{3}$ For discussions of the origins of the crisis from the IMF's perspective, see for instance World Economic Outlook December 1997 and April 1998; and International Capital Markets: Developments, Prospects, and Policy Issues 1998. Some academic surveys of the 
which have been discussed at length in a previous paper, ${ }^{4}$ rather, the paper will use these events to examine various aspects of the strategy followed in responding to the crisis, contrasting them with alternative approaches that have been proposed.

The paper is structured as follows. Section 2 discusses the strategy of the programs adopted in response to the crisis, contrasting it with some alternatives that have been proposed. Section 3 briefly reviews the macroeconomic events that unfolded through the crisis. Section 4 discusses the essential implications of external financing in the countries affected; Section 5 discusses the role of monetary policy, including concerns that the tightening may have been counterproductive given the compromised state of the countries' financial systems. Section 6 discusses the role of fiscal adjustment. Section 7 discusses the strategy of structural reform in the programs. Section 8 concludes with some general lessons.

\section{The Strategy of The Programs}

Financial sector vulnerability was at the root of the Asian crisis. In most of the countries affected, conventional macroeconomic imbalances were of limited importance in accounting for the crisis. In contrast to standard cases of balance-of-payments problems, in which the monetization of fiscal imbalances and the maintenance of unsustainable exchange rates are key elements, these problems were generally absent in most of the countries affected. Thailand, however, the country that triggered the crisis, was closer to the classic case: the exchange rate was widely viewed as somewhat overvalued, with the external current account deep in deficit, and the fiscal position had swung into deficit in the runup to the crisis-although even these significant macroeconomic problems are probably not sufficient in themselves to account for the intensity of the ensuing market response.

Two main types of vulnerability were important in setting the stage for the crisis and, in large part, accounting for its virulence. First, in all the countries affected, mounting problems in the financial system, associated with festering (albeit often unacknowledged) non-performing loans and swings in real estate and equity prices sowed doubts about the credit-worthiness of borrowers in these countries and gradually undermined confidence in the currencies. Second, unhedged exposure to short-term foreign-currency-denominated debt created the scope for self-reinforcing debt runs and a vicious spiral of depreciation and deepening insolvency that started once the currencies began to depreciate. These weaknesses were particularly problematic in the context of high debt-equity ratios characterizing financial and non-financial corporations in most countries in the region. These vulnerabilities in turn reflected the liberalization of domestic financial systems and capital flows without adequate preparation with regard to supervision and regulation; lax monetary policies

origins of the crisis include Radelet and Sachs 1998 and 1999; and Corsetti, Roubini, et al. 1998.

${ }^{4}$ See Lane and others, 1999. 
reflected in rapid domestic credit expansion; and stable exchange rates, which lulled some borrowers into a false sense of security with regard to their exchange rate exposures.

These vulnerabilities created the conditions for a crisis whose hallmark was a sharp reversal of international capital flows. This reversal affected mainly short-term debt issued by the private sector including financial institutions. The reversal of capital flows in turn was associated with a wrenching correction in the external current account, amounting to over 20 percentage points of GDP in Thailand, 15 percentage points in Korea, and over 4 percentage points in Indonesia (from trough to peak). When the IMF-supported programs were put in place, it was known that a significant change in capital flows was under way, but the magnitude of the correction was not: initial program projections foresaw a relatively gradual current account adjustment, whereas the actual result was much more drastic (Figure 1). It was also not foreseen at the outset that these economies would adjust in a dysfunctional way to reduced external financing-largely through a collapse of private domestic demand rather than a boom in exports. ${ }^{5}$ This adjustment reflected in large part the harsh balance-sheet effects of the currency depreciations that occurred, given the unhedged foreign currency exposures of banks and corporations. ${ }^{6}$

As in any IMF-supported program, the strategy of policies adopted in response to the crisis was three-pronged, combining financing, macroeconomic policy adjustment, and structural reforms. However, each of these elements needed to be adapted to the fact that this was not a standard kind of crisis.

Exceptionally large official financing packages were provided to Indonesia, Korea, and Thailand, including both the funding provided by the IMF and other multilateral financial institutions (World Bank and Asian Development Bank) and commitments of substantial bilateral support. In a crisis of this nature, financing has two purposes: in addition to reducing the magnitude of current account adjustment forced by a given change in private capital flows, it is also intended to influence those flows by restoring confidence.

\footnotetext{
${ }^{5}$ Krugman (1999) presents a simple model illustrating the dilemmas facing policymakers in a crisis brought on by financial sector weaknesses.

${ }^{6}$ Gray (1999) examines the impact of exchange rates on corporate balance sheets in Asian countries, finding a substantial impact from a currency depreciation.
} 
Figure 1. Indonesia, Korea and Thailand : Sectoral Savings-Investment Balances $1 /, 2 /$

(In percent of GDP)

Initial program

Most recent review 3/

Indonesia
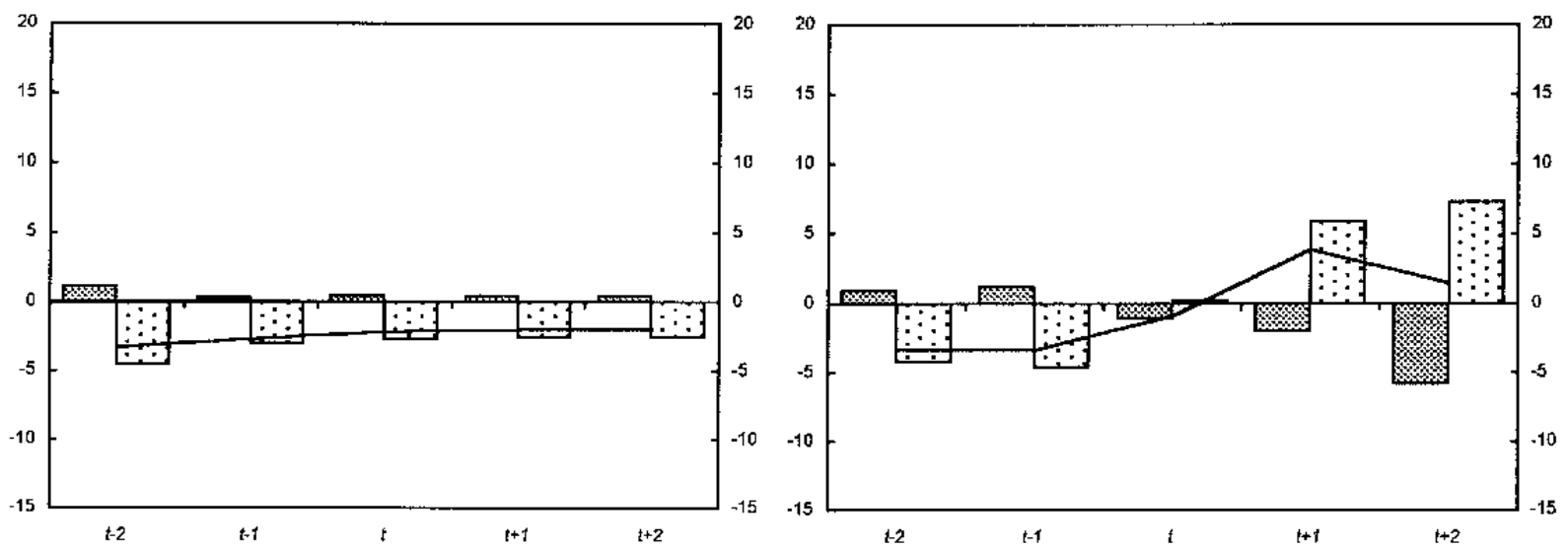

Korea
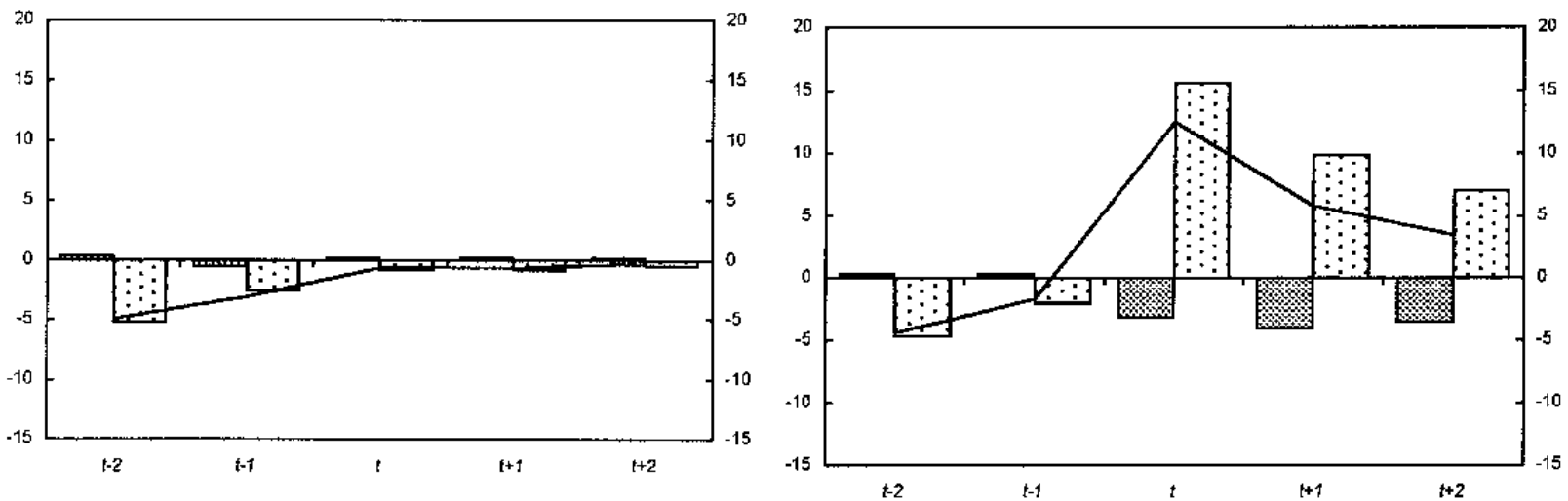

Thailand

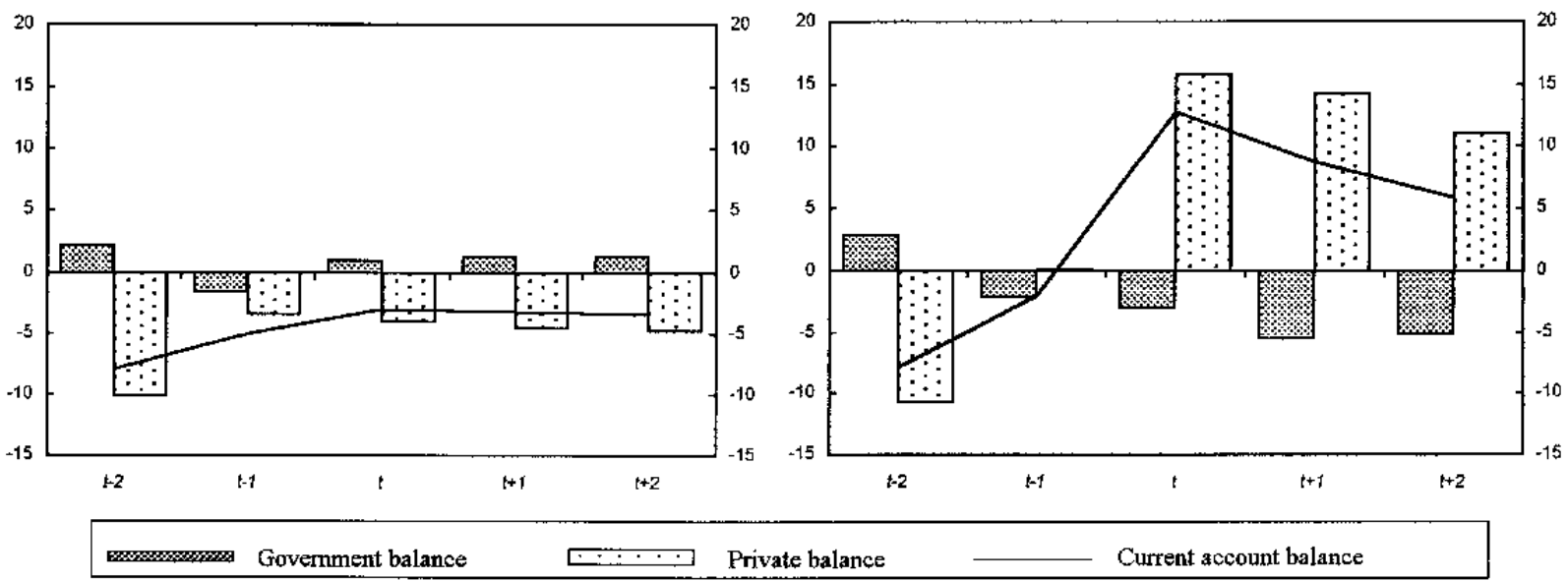

Source: Intemational Monetary Fund.

1/ Private sector savings-investment balances are calculated residually as current account balances minus government balances. $2 / t$ is the initial program year : Indonesia (1997/98), Korea (1998), Thailand (1997/98). In most cases, data for the preprogram year, $(t-1)$, have been revised since the original programs were formulated.

3/ "Most recent rcvicw" refers to the Jatest available full medium-term projections as follows: For Indonesia, sixth review of Extended Fund Facility, July 1999; for Korea, sixth review of Stand-By Arrangement, September 1999; and for Thailand, eighth review of Stand-By Arrangement, September 1999. 
Macroeconomic policies were another key element in the strategy. In most IMF-supported programs, fiscal adjustment is a central pillar. In the Asian crisis, the role of fiscal policy was different, since conventionally measured fiscal imbalances were not a major element in the existing problem: and the sustainability of public debt was not a concern in any of the countries. ${ }^{7}$ The initial programs prescribed comparatively small fiscal adjustments, aimed at taking up some of the burden of external current account adjustment and boosting confidence by signaling that the costs of the required bank restructuring would be met within existing budgets. In Thailand, there was also additional fiscal adjustment to offset the increase in the fiscal deficit that had occurred in the runup to the crisis. As the crises unfolded, it soon became apparent that even this magnitude of fiscal adjustment was excessive, in light of the collapse of private domestic demand that was under way; fiscal policy then went into reverse (albeit, in hindsight, too slowly), accommodating a substantial widening of deficits to support economic activity. It would have been more difficult to justify such a reversal had the crisis been primarily fiscal in origin.

Monetary policy faced a difficult task in the programs. Before the countries turned to the IMF for support, market pressures had forced them to abandon the formal or informal exchange rate pegs that had been the central pivot of their policies. Re-pegging at a more depreciated rate was rejected, as this would have required a commitment to use monetary policy unstintingly to defend the rate, and reserves were depleted (in all countries except Indonesia). Once the decision had been taken not to try to re-peg, it became difficult to make any alternative anchor credible — such as an inflation target, a monetary target, or a commitment to repeg at pre-crisis parities once markets calmed down. ${ }^{8}$ Policymakers were thus in a world of discretion influenced by frequent consultation with Fund staff and at times constrained by informal understandings about exchange rate and interest rate policies.

(Formal performance criteria on official reserves and credit aggregates set in connection with the IMF-supported program were also in place, but these were generally not binding). ${ }^{9}$ The basic approach followed in this setting was to tighten policies to counter some of the downward pressure on currencies, without attempting to adhere to any set target for the level of the exchange rate.

\footnotetext{
${ }^{7}$ At the same time, it should be noted that conventional measures may have overstated the strength of these countries' fiscal positions as they understated the prospective fiscal burden of financial sector restructuring. Some observers (notably Burnside, Eichenbaum, and Rebelo, 1999) argue that these contingent liabilities were central to the onset of the crisis.

${ }^{8}$ See Vines and Corbett (1999); McKinnon (1999).

${ }^{9}$ The desire to allow a degree of flexibility in a highly uncertain environment, with possibly unstable money demand, argued against setting quarterly reserves floors or credit ceilings very closely to the values projected in a program's baseline scenario.
} 
Structural policies were an unusually important element in the programs with Indonesia, Korea, and Thailand. In particular, reforms in the financial and corporate sectors were needed to address the root causes of the crisis with a view to restoring confidence and preventing a recurrence. In addition, there was a need to clear the wreckage of insolvency that began to emerge prior to the crisis and was exacerbated by the pernicious balance-sheet effects of the crisis itself. Moreover, as in many Fund-supported programs, structural reforms were intended to increase the economy's resilience and lay the foundation for long-run growth. Another important goal, as in many programs, was to establish a well-targeted social safety net to cushion the poor and vulnerable from the pains of adjustment.

The initial results of the Fund-supported programs in Indonesia, Korea, and Thailand were not what had been hoped. In particular, the programs were not at first successful in restoring confidence: on the contrary, capital continued to exit and the currencies continued to depreciate after the programs had been adopted. Moreover, the economies sank into deep recessions, contrary to initial projections of only a mild slowdown. There is no question that these early results of the programs were disappointing - although some of the criticism has become more muted in recent months as the economies affected have returned to growth. But in addressing the lessons of the crisis, the key question is whether there was something wrong with the basic strategy followed, or whether problems encountered were in the way this strategy was implemented, or were essentially unavoidable consequences of this kind of crisis.

Criticisms of the basic strategy of the programs have come from two different points of view. One line of argument starts from the premise that the crisis was basically a liquidity panic resulting from short-term foreign currency exposures - analogous to a bank run (Radelet and Sachs, 1998). It has thus been argued that the three-pronged approach sketched above only exacerbated the panic, by giving investors the misleading impression that something was fundamentally wrong with these economies. On this view, structural reforms were a distraction that imposed costs on economies already coming under strain (Furman and Stiglitz, 1999). Fiscal and monetary tightening undermined confidence by contributing to the economic downturn and raising fears of insolvency, thus adding to downward pressures on exchange rates. The implication of this view is that a more appropriate policy response would have concentrated on restoring confidence quickly by providing much larger financing to the countries affected through even larger official packages and/or by imposing standstills and capital controls on private creditors to stop the rush to the exits (Yoshitomi and Ohno, 1999). On this view, monetary and fiscal policies should if anything have been eased, not tightened, at the outset, to the extent that this was needed to support economic activity. To the extent that structural reforms were needed, they should have been undertaken more gradually and only as the economy recovered from the effects of the crisis.

The policies eventually adopted by Malaysia during this period, with capital controls and smaller increases in interest rates, are sometimes interpreted as an illustration of this alternative approach. In reality, however, these policies were less different than they seem from those of other countries in the region. Moreover, as Malaysia's capital controls were introduced in September 1998, after market conditions had stabilized and capital outflows 
abated, they hardly provide a test of the usefulness of capital controls in handling a crisis. ${ }^{10}$ Malaysia's policies and experience are discussed in Box 1.

The Fund-supported programs in Asia have also been criticized, in effect, for trying to do too much to restore confidence. Here, the argument is that investors and countries that made imprudent decisions should pay for those decisions, and providing additional official financing in the event of a crisis blunts the effects of market discipline. This argument suggests that the availability of $\mathrm{IMF}$ and other official financing engenders moral hazard, making future crises more likely. ${ }^{11}$ On this view, it would be preferable to let crises run their course. (Proponents of this view are divided as to whether countries should be encouraged to default more or less frequently on their external obligations.)

That the potential availability of future IMF financing could induce moral hazard is an influential argument for benign neglect toward financial crises, and one which deserves to be addressed. ${ }^{12}$ For practical purposes, however, moral hazard is a question of degree--not whether borrowers and lenders engage in risky behavior, but how much riskier their behavior is made by existence of the IMF. So far, there is little evidence on this question, and indeed it has proven difficult to detect evidence of IMF-induced moral hazard (Lane and Phillips forthcoming, see also Box 2). Moreover, Nunnenkamp (1999) and Willett (1999) both point to evidence on the composition of capital flows as contradicting the moral hazard hypothesis. On the other hand, Kho and Stulz (1999) find that the announcement of the IMF involvement in Korea evidently increased the value of domestic and foreign banks with Korean exposure. Of course, even if the IMF's contribution to moral hazard could be isolated and quantified, this would settle nothing in itself, since any welfare costs along these lines would need to be weighed against the benefits of the Fund's role in containing the total economic costs of crises, both within and across countries.

${ }^{10}$ Another experience that may be more relevant is Thailand's imposition of capital controls in May 1997. These controls were unsuccessful in staunching capital outflows, and the baht had to be floated two months after the controls were imposed.

${ }^{11}$ Examples of recent critiques of IMF financial support based upon moral hazard are Calomiris, 1998; Meltzer, 1998; and Vásquez, 1998.

${ }^{12}$ A recent paper (Zettelmeyer 1999) presents an interesting game-theoretic argument suggesting another possibility: that an intermediate size of financing package may be more subject to attack than either a large or a small one. It remains to be examined whether this "case against partial bailouts" is supported by empirical evidence. 


\section{Box 1. Malaysia}

Malaysia faced many of the same problems as the other Asian tigers. Its approach to crisis management was somewhat different from those of countries that adopted IMFsupported programs. But these well-publicized differences have often been exaggerated: the policies pursued by the Malaysian government were in many respects quite similar to those in neighboring countries.

Malaysia: Selected Economic Indicators, 1996-99

\begin{tabular}{|c|c|c|c|c|}
\hline & 1996 & 1997 & 1998 & $\begin{array}{c}1999 \\
\text { Projection }\end{array}$ \\
\hline \multicolumn{5}{|c|}{ Real GDP growth (in percent) } \\
\hline Malaysia & 8.6 & 7.7 & -6.7 & 2.4 \\
\hline Regional average $\underline{1} /$ & 6.9 & 4.3 & -7.2 & 1.6 \\
\hline \multicolumn{5}{|c|}{ Current account balance (in percent of GDP) } \\
\hline Malaysia & -4.9 & -5.1 & 12.9 & 10.5 \\
\hline Regional average $\underline{1} /$ & -5.1 & -3.0 & 8.3 & 6.0 \\
\hline \multicolumn{5}{|c|}{ Overall fiscal balance (in percent of GDP) } \\
\hline Malaysia & 1.1 & 2.6 & -1.5 & -3.8 \\
\hline Regional average $\underline{1} /$ & 0.8 & 0.2 & -2.3 & -3.5 \\
\hline \multicolumn{5}{|c|}{ Broad money growth (in percent, end-year) } \\
\hline Malaysia & 23.7 & 20.2 & -1.6 & 11.2 \\
\hline Regional average $\underline{1} /$ & 19.7 & 15.8 & 17.3 & 13.3 \\
\hline
\end{tabular}

Sources: Information provided by the authorities; and Fund staff estimates and projections.

1/ Indonesia, Korea, Malaysia, Phillipines, and Thailand; simple average.

Similar to other countries, Malaysia experienced severe losses in investor confidence and, consequently, large capital outflows starting in mid-1997. At the fundamental level, this reflected skepticism as to whether the country could sustain the double-digit rates of growth of private sector credit, large current account deficits (5-10 percent in 1995-97), and high prevailing asset prices. As a result, through mid-1998, the stock market plunged by 60 percent, the exchange rate depreciated by 25 percent in real effective terms, and international reserves declined by one-fourth in U.S. dollar terms. 
Regional similarities notwithstanding, several features of the Malaysian economy prior to the crisis helped to avoid it the extreme financial difficulties experienced by others. First and foremost, Malaysia had a stronger financial position with limited external exposure, ${ }^{1}$ while sharing the large fiscal surpluses, low inflation, and high private savings rates of the other countries. Second, a relatively well-developed regulatory, legal, and accounting framework for the financial system was in place and, at the onset of the crisis, the authorities were able to strengthen this framework even further. Finally, a comparatively low incidence of poverty and some degree of labor market flexibility, owing to expeditious repatriation of foreign workers, helped mitigate the domestic social impact of the crisis.

The initial reaction of Bank Negara Malaysia — similar to other central banks - was to ward off the attacks by sharply raising interest rates: overnight rates rose from 6 percent in June 1997 to 35 percent in July 1997. Soon thereafter, however, the rates were allowed to fall back to below 10 percent and the authorities focused on tightening monetary conditions instead through various direct instruments such as credit plans for financial institutions and a ban on new lending to the property sector. In the end, the 12-month growth rate of broad money declined gradually from the mid-twenties in 1996-97 to single digits by mid-1998 and overnight interest rates peaked at above 10 percent at the same time.

Fiscal policies were supportive of the stabilization efforts and Malaysia maintained the tightest stance of all the crisis countries. Malaysia's overall surplus was increased to $21 / 2$ percent of GDP in 1997 and only in mid-1998, when the demand conditions began to signal a severe recession, was the budget made somewhat expansionary, ending the year with a modest deficit of $11 / 2$ percent of GDP. In all, Malaysia's fiscal policy response was significantly more contractionary than that of countries that adopted MF-supported programs and the relaxation in response to indications of the severity of the recession came later than elsewhere.

In September $1998,{ }^{2}$ when conditions in currency and stock markets had already broadly stabilized and export growth had begun to recover, Malaysia imposed wide-ranging capital controls aimed at eliminating the off-shore ringgit market which was seen as stimulating capital outflows, ${ }^{3}$ and penalizing short-term portfolio inflows. At the same time, the exchange rate was fixed at 3.8 ringgit per U.S. dollar, a level at which the ringgit was undervalued relative to other regional currencies. Initially all off-shore ringgit funds had to be brought on-shore by end-September 1998 and a one-year holding requirement was applied to the repatriation of funds from sale by nonresidents of their portfolio investments in Malaysian securities; in February 1999 this regulation was replaced by a two-tier system of exit levies, and in September 1999 the system was further simplified as a flat 10 percent exit levy. ${ }^{4}$ 
To what extent did these controls help to stabilize external developments and, consequently, the economy? It would be difficult to attribute much of the stability to capital controls. First, these controls were imposed some 14 months after the crisis started, by which time most of the short-term speculative capital may already have left (although the outflow that occurred after the controls were lifted in September 1999 suggests that these controls were not completely immaterial). In addition, the exchange rate was fixed at a level that was undervalued relative to other regional currencies. Second, their effects were limited, as the levy applied to profits excluding interest payments. Hence, fixed-income flows were constrained much less than other flows. Third, at the onset of the crisis, the Malaysian authorities embarked on wide-ranging reforms in the regulatory and supervisory framework for the financial sector; high compliance with accounting principles as well as with supervisory requirements helped make these reforms more effective. The improvements in prudential regulation may have done more to restore confidence and help stabilize the ringgit than the capital controls.

By mid-1999, Malaysia's performance appeared to be quite similar to that of other countries in the region. After a sharp fall in 1997-98, industrial production was beginning to pick up, even though private sector credit growth remained subdued. The current account was poised for large surpluses in 1998-99, mainly reflecting lower domestic demand as in the other countries in the region. However, the risk premium on Malaysia's sovereign bonds remained one of the highest in the region, although it has recently come down to about 20 basis points.

${ }^{1}$ Malaysia had smaller external debt (40 percent of GDP), with only 20 percent of that debt being short-term, and insignificant private nonbank debt (US $\$ 2$ billion).

${ }^{2}$ Prior to September 1998, Malaysia's capital control regime was comparatively liberal and the ringgit was freely traded off-shore. For a detailed account of capital account regulation, see Malaysia-Selected Issues, August 1999.

${ }^{3}$ Off-shore ringgit interest rates were consistently $20-30$ percentage points higher than those on-shore.

${ }^{4}$ The experience with these capital controls is discussed in more detail by Adams and others, 1999 
Box 2. Does IMF Support Induce Moral Hazard?

The degree of moral hazard induced by IMF financial support has so far remained largely a matter for speculation. In the meantime, in the absence of more systematic evidence on the question, one can note two sets of factors that likely limit the scope of Fund-induced moral hazard.

On the side of the member country:

- Unlike other forms of insurance, disbursements of IMF resources are not a cash payoff. Rather they are loans, to be repaid with interest. (Thus if investors are eventually bailed out of crises, it is not by the Fund, but by debtor countries themselves, and in a long-run sense. In the end, any "bail out" is funded by a member's own saving flows, as reflected in its external current account.)

- The crises that IMF-supported programs address are most often a very unpleasant experience for incumbent governments and their constituents.

- Programs' conditionality often requires structural reforms to curtail risky behavior, lessening the chances of future crises (and also ensuring that the Fund's resources will be returned).

On the side of foreign investors

- Fund financial support does not prevent losses; ex post, many investors are clearly seen to suffer losses.

- In a given crisis, some investors may get off scot-free. What matters for moral hazard, however, are not specific actual outcomes, but expectations of what will happen in future crises. Certainly, there is no sign yet that investors perceive anything like a full guarantee from the IMF. The evidence suggests investors believe that they live in a risky world:

- Interest rate spreads vary widely across Fund member countries, and over time.

- The simple fact that crises of capital flight continue to occur, and that they do not end immediately upon announcement of IMF financial support. Presumably, investors have observed that Fund financial support, even when exceptionally large, tends to be much smaller than what would be needed to imply a full, and credible, guarantee. 
Analysis of spreads on dollar-denominated bonds (Lane and Phillips, forthcoming) does not find much sign that markets are sensitive to announcements that might convey information on the likely availability of IMF financial support in future crises--such as the large 1995 support for Mexico, an increase in Fund lending limits, or the increase in Fund quotas-although this could be due to low power of the test. (For example, investors in Korea in early 1995 may have seen the Fund's involvement in Mexico as irrelevant to their case if they had already ruled out the possibility that Korea would one day need IMF financial support. On the other hand, Willett (1999) notes that the negative political reaction to the support to Mexico could have lowered investors' expected returns.

Aside from such criticisms of the basic strategy of IMF-supported programs in the Asian crisis countries, there are several acknowledged problems of judgement and implementation, both on the part of the national authorities and the Fund, that undermined confidence at the outset and imperiled the recovery. These include initial hesitations in monetary tightening and stop-go policies; poor timing of revelation of the parlous state of the countries' reserves (in Korea and Thailand); the lack of credibility with which some elements of the announced official financing packages were committed (the "second lines of defense" in Indonesia and Korea which in fact were never disbursed); the fact that the closure of 16 banks in Indonesia, while necessary, was not coupled with an adequate strategy to deal with banks that were not closed and compensate their depositors; interest rates set on foreign currency advances that were overtaken by market rates and thus accelerated the exit of foreign exchange from the country (in Korea); and ineffective communication of the logic behind the programs to the public and the markets. In addition, there were largely exogenous circumstances, including the weakness of the Japanese economy and various electoral and other political developments in all three countries, that dampened confidence and undermined the economy.

In addition to operations of the basic strategy and its implementation, there are also bound to be disagreements on questions of degree: one can, for instance, agree that official financing was needed but dispute whether these packages were large enough; one can agree that monetary tightening was needed but believe that in some cases it went too far (or not far enough); one can agree that fiscal policy should have been eased once the recession became evident, but argue that the need for easing should have been recognized sooner; one can agree that structural reforms were needed, but nonetheless argue that these reforms should have been better focused on the core of financial and corporate reforms.

In the remainder of the paper, we will consider, with the benefit of hindsight, whether the problems encountered reflected weaknesses in the basic strategy, or problems of implementation and degree, or were largely the unavoidable consequences of the kind of crisis being experienced. We will first review the unfolding of the crisis and then examine specific aspects of policy and their implementation. 


\section{The Evolution OF THE CRISIS}

The sweep of the Asian financial crisis can be seen first of all in the financial markets. Currencies that had been stable for many years depreciated precipitously-in the case of Indonesia, declining to one-fifth of their pre-crisis level, and in the other countries to 50-60 percent of pre-crisis levels (Figure 2). Exchange rates recovered again beginning in early to mid-1998, with the timing differing across countries; by mid-1999, they were only moderately depreciated in real effective terms compared with pre-crisis levels (17 percent weaker in Korea, 19 percent in Thailand, and 25 percent in Indonesia). ${ }^{13}$

These financial market developments were accompanied by severe recessions in the economies affected. After a history of rapid growth, economic activity slumped in these countries, by amounts ranging from 6 percent in Korea to 15 percent in Indonesia in 1998 (Figure 3). This reflects mainly a severe contraction of private domestic demand, which was only partially offset by the rise in net exports. In particular, collapses in private investment spending account for much of the decline in GDP (Figure 4). Private consumption also declined, roughly in line with the decline in national income. These declines reflected a combination of the balance sheet and other effects of currency depreciation and monetary tightening, as well as the decline in confidence. The contribution of government consumption to growth in 1998 was close to zero in all these countries.

The recovery began in the second or third quarter of 1998 in Korea, as the collapse in domestic demand reversed itself while net exports continued to make a positive contribution to growth. In Korea, the resurgence of domestic demand reflected a strong rebound in private consumption, reflecting in part the revival of demand for consumer durables, as well as strong investment in equipment and a slower pace of inventory decumulation. ${ }^{14}$ In Thailand, there is preliminary evidence that the recovery is broad-based, including both consumption and investment. By mid-1999, GDP had surpassed its mid-1997 level in Korea and the Philippines, but not yet in the other countries. In Indonesia, while recovery appears to have begun in mid-1999, growth is expected to be close to zero for 1999 as a whole and resume only weakly in 2000 .

${ }^{13}$ In the Philippines, the initial situation, the policy response, and the evolution of the crisis were different than in the crisis countries that are the primary focus of this paper. See Box. 3 .

${ }^{14}$ A deceleration in the pace of inventory decumulation made a relatively strong contribution to growth in Korea in the first two quarters of 1999, although in levels inventories continued to fall. 
Figure 2. Indonesia, Korea, Malaysia, Philippines and Thailand: Nominal and Real Effective Exchange Rates, June 1997 - June 1999

Indonesia $\quad($ June $1997=100) \quad$ Korea
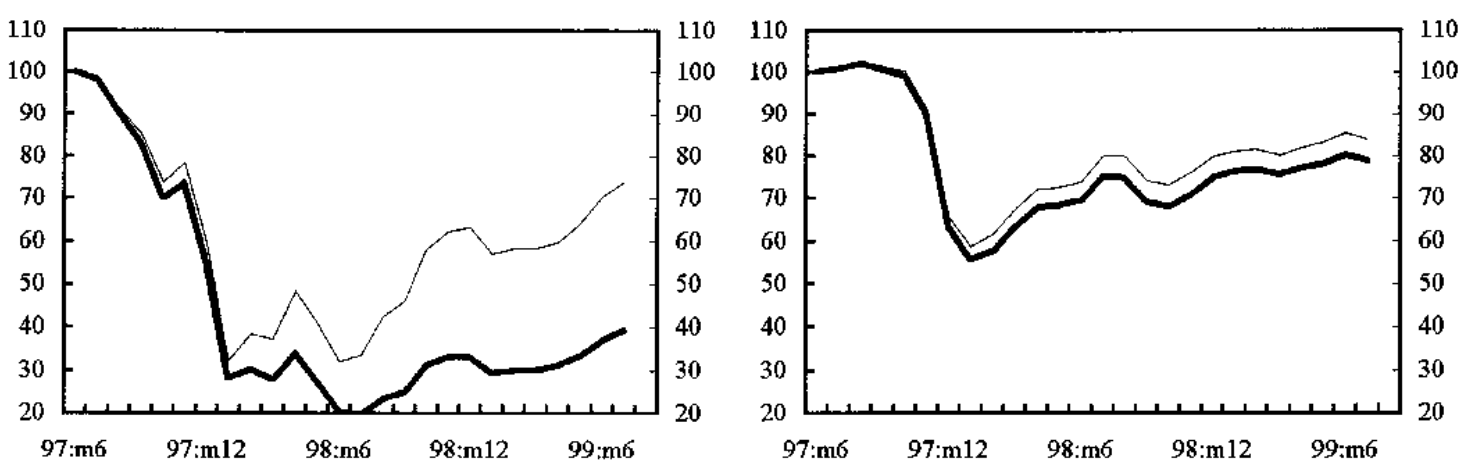

Malaysia

Philippines
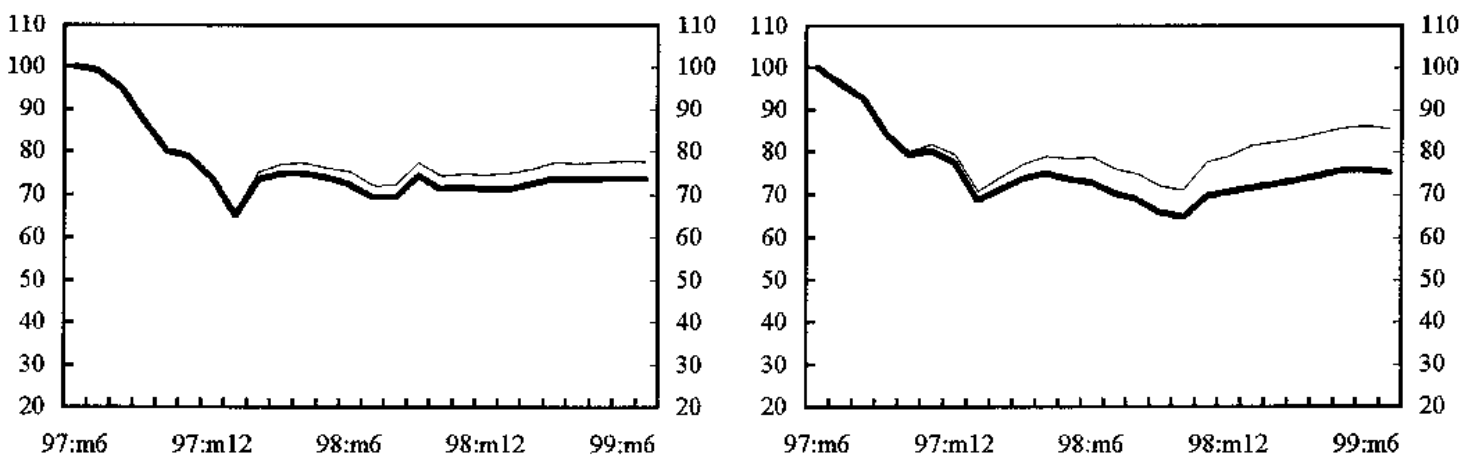

Thailand

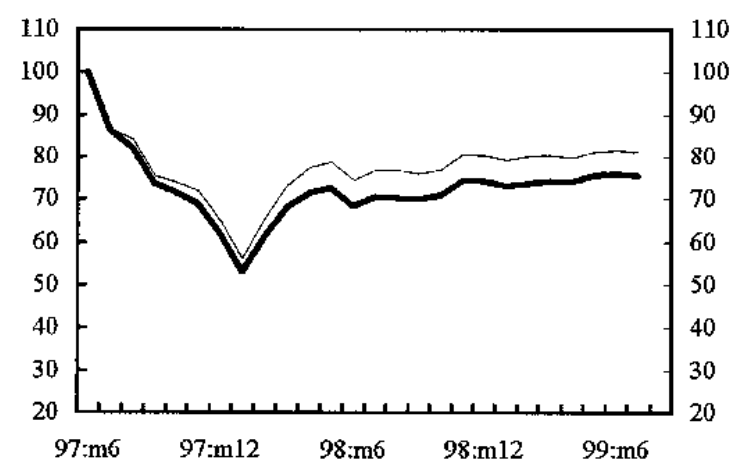

Nominal effective exchange rate Real effective exchange rate

Source: International Monetary Fund, Information Notice System. 


\section{Box 3. Philippines}

The Philippines managed to survive the Asian crisis with less pain than other countries in the region. What was different about the Philippines? First, in their macroeconomic performance in the 1970s and 1980s, the Philippines lagged behind their neighbors and only after reforms in the early 1990 s did the economy begin to attract substantial foreign direct investment. Consequently, signs of overheating and financial imbalances began to show much later than in other countries. Secondly, at the time of the crisis, an IMF arrangement ${ }^{1}$ was already in place and, when the crisis struck, the authorities acted decisively. The consensus for sound economic policies survived the May-July 1998 transition from one presidential administration to another.

At the onset of the crisis, the Philippines presented a different pattern of strengths and vulnerabilities than the "tigers" most heavily affected by the crisis. Current accounts deficits averaged 4-5 percent in recent years and private sector credit grew 50 percent in 1996. However, by regional standards, the pre-crisis growth rates of real GNP were more modest than in other countries and external exposure, including short-term debt, was relatively small. Moreover, levels of corporate leverage were significantly lower, major banks were well capitalized, and the reforms of the past 10 years or so had created a reasonably open, marketoriented economy.

The impact of the Asian crisis - in terms of the initial drop in share prices, currency depreciation, and loss in international reserves-was comparable to the Philippine neighbors. On the other hand, the ensuing recession was relatively mild and most of the macroeconomic and financial indicators rebounded faster than in Thailand or Korea. This may have reflected, in large part, the lesser degree of vulnerability of the Philippine economy; it was also associated with more favorable export performance than in neighboring countries.

As in other countries, a decline in capital inflows and sharp falls in the stock market led to mounting pressures on the peso. The authorities initially tightened monetary policy by raising interbank interest rates from about 15 percent to reach peaks of $40-60$ percent (for a few days in late August 1997) and intervened in the foreign exchange market to maintain the de facto peg of the peso. ${ }^{2}$ However, the system lost its viability with the flotation of the Thai baht and the peso was accordingly floated in July 1997. The new exchange rate arrangement was accompanied by strengthened fiscal, monetary, and structural policies in the context of the existing Fund program. 
After initial monetary and fiscal tightening, as the peso stabilized, the stance gradually shifted toward supporting the emerging recovery. Interest rates were brought down during the second half of 1998 and monetary policy was eased significantly in early 1999, after firm turnarounds in the balance of payments and inflation were established. Fiscal policy followed a similar path: from a pre-crisis surplus target of 1 percent of GNP for 1998, the program was revised to an eventual deficit target of 3 percent of GNP.

Financial markets remained volatile until the last quarter of 1998, as a result of both external developments and domestic uncertainties (including political uncertainties associated with a new administration). Since September 1998, financial markets strengthened continually, with share prices up by more than 100 percent above their bottom, the peso appreciated by some 20 percent in real effective terms, and official reserves rising well above their pre-crisis level. By mid-1999, the economic slowdown appeared to be over, with industrial production showing significant growth. GDP is projected to grow by about 3 percent in 1999.

${ }^{1}$ The Philippines has had a long history of Fund programs. The Extended Fund Facility, with total access of SDR 0.8 billion, had been in place from June 1994. The arrangement was extended in July 1997 and also the total amount approved was augmented. A new two-year stand-by arrangement, with total access of SDR 1 billion, was approved in April 1998.

${ }^{2}$ The authorities effected their operations primarily through Nondeliverable Forward Interventions (NDF). In these interventions, the notional amounts of each currency do not have to be delivered at maturity and, instead, settlement takes place for the difference between the forward and spot rate at maturity. This type of intervention is generally less transparent than direct interventions using net international reserves (NIR) of the central bank, and has the obvious purpose of generating inflows into the spot market without using official reserves. Operationally, the central bank "invited" selected foreign-owned commercial banks to borrow abroad and sell the proceeds in the local foreign exchange market. The agent's exposure would then be hedged with the NDFs provided by the central bank. In the event these operations yielded profits for the central banks, although the amount of these profits has not been disclosed. 
Figure 3. Indonesia, Korea, Malaysia, Philippines and Thailand: Indicators of Economic Activity, March 1997 - June 1999

Real GDP

$(1997: Q 1=100)$

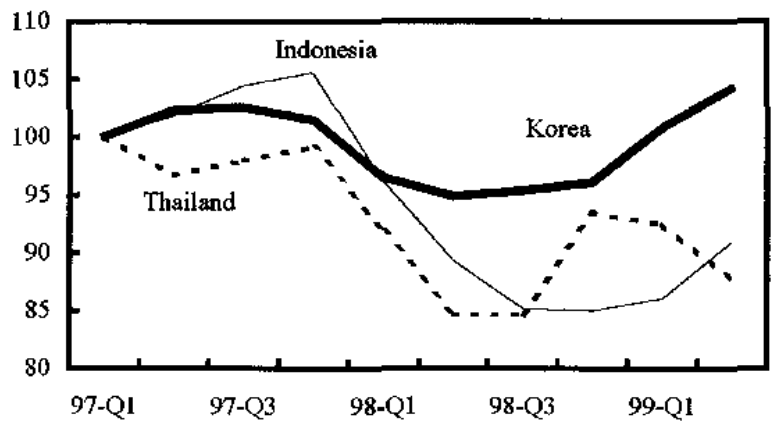

Industrial Production

(January 1997=100)

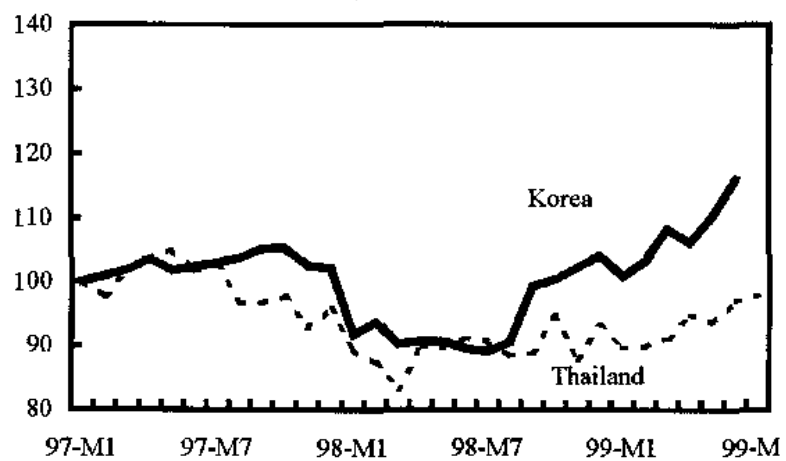

Export Value in US dollars

(Year-on-year growth rates;

6-month moving average)

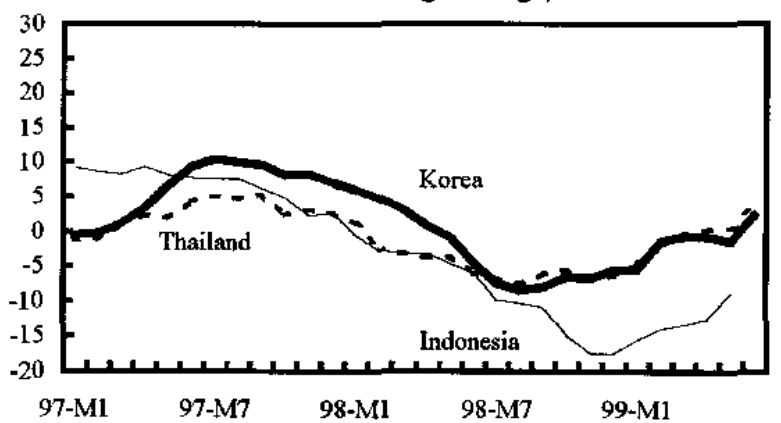

Real GDP

$(1997 \mathrm{Q} 1=100)$

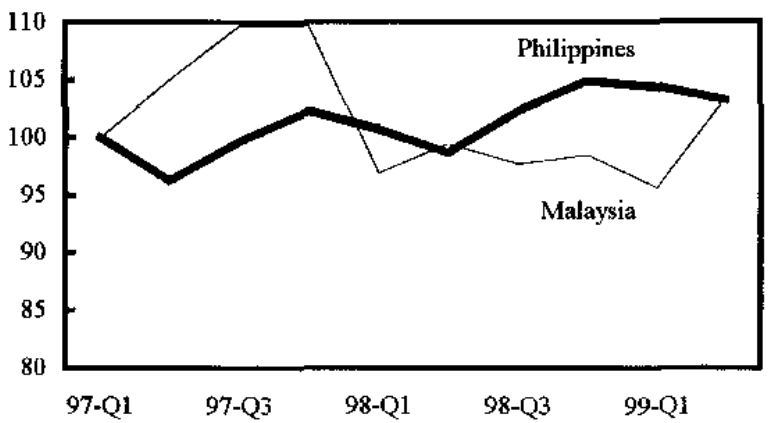

Industrial Production

(January 1997=100)

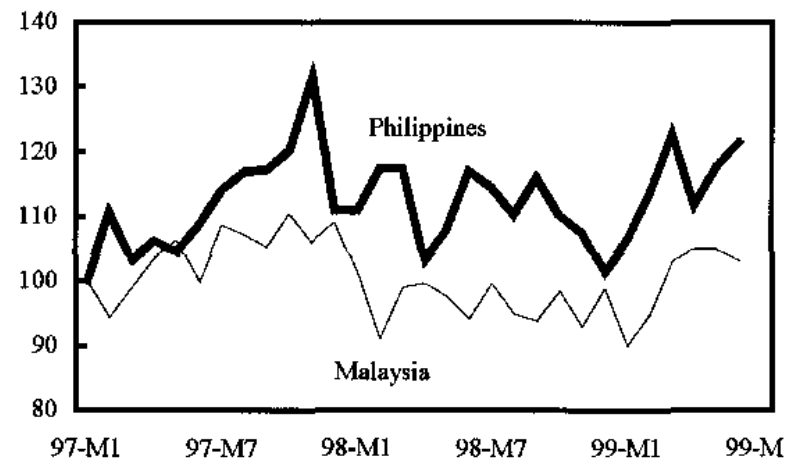

Export Value in US dollars

(Year-on-year growth rates

6-month moving average)

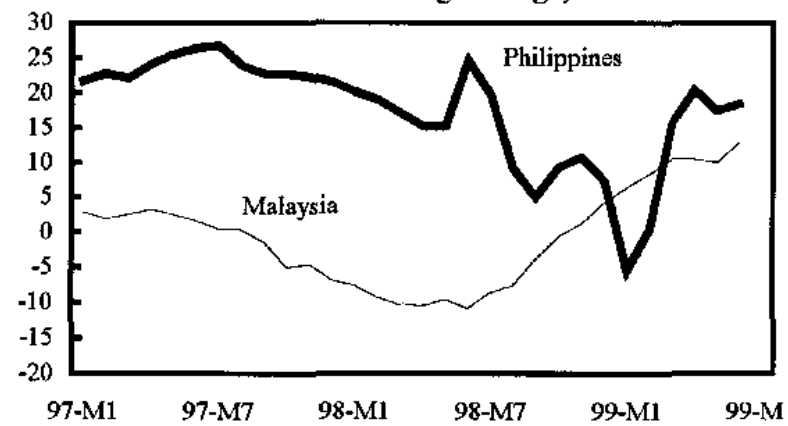

Sources: International Monetary Fund, International Financial Statistics; Bank of Indonesia; Bank of Thailand and Fund staff estimates. 
Figure 4. Indonesia, Korea, Malaysia, Philippines and Thailand: Contributions to GDP Growth, 1997-2000

Indonesia

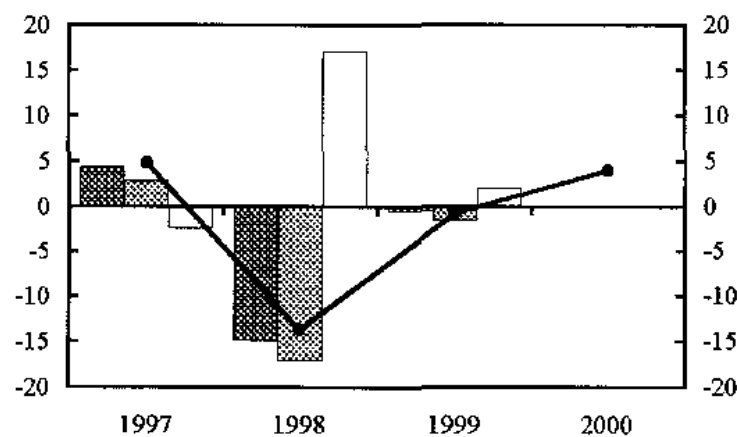

Malaysia
Korea

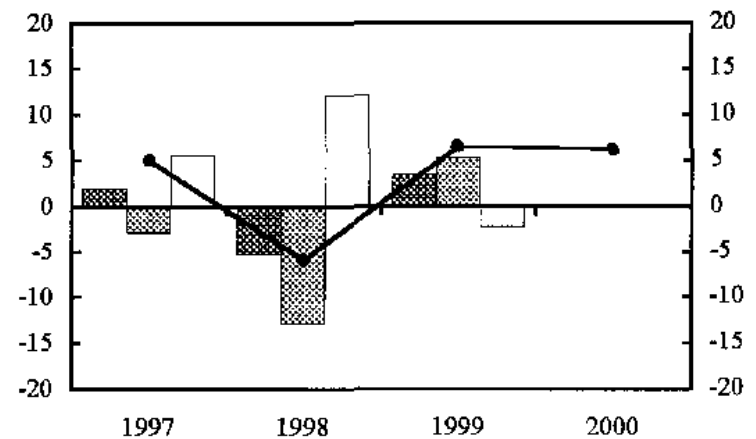

Philippines
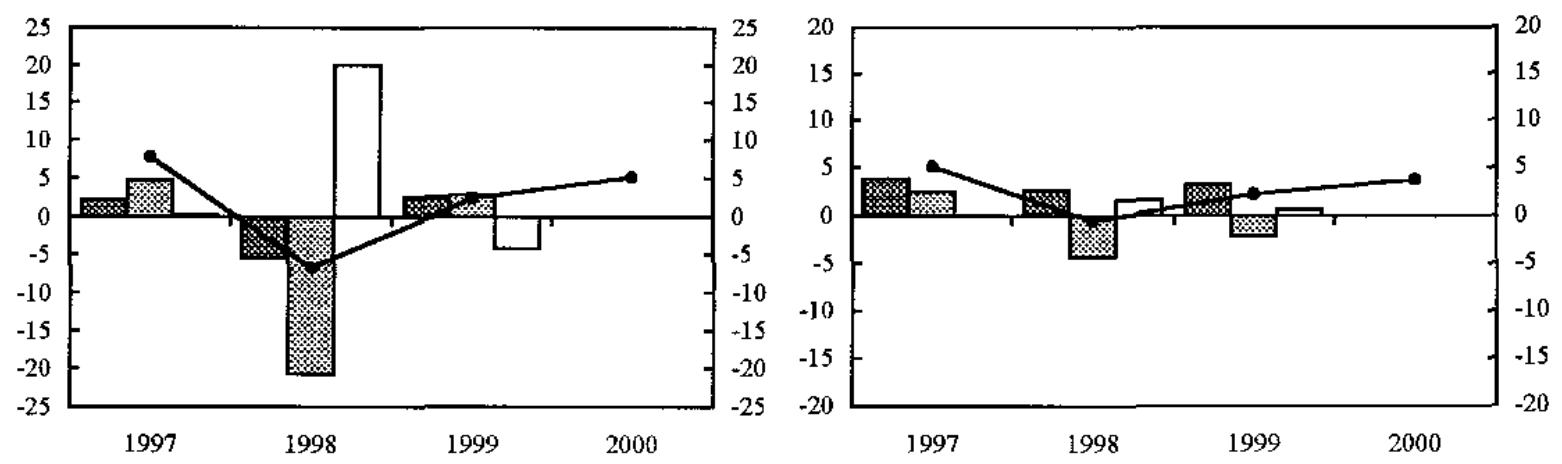

Thailand

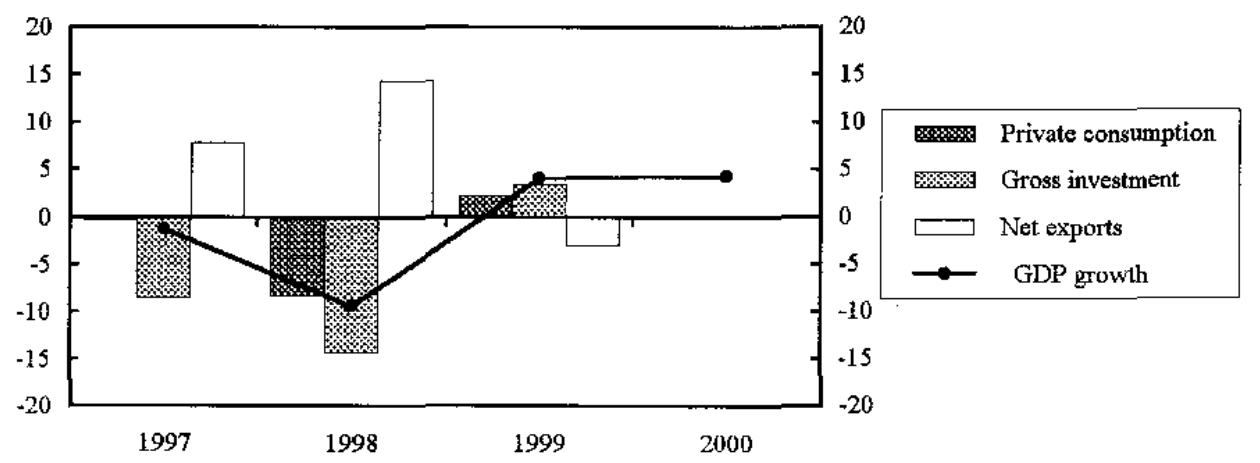

Source: International Monetary Fund, World Economic Outlook; Consensus Forecasts, August 1999. 
The decline in output and its subsequent recovery were coupled with equally dramatic movements in external current accounts, which swung into surplus, corresponding to the reversal of capital inflows (Figure 5). The current account improvement reflected import compression to a greater extent than rising exports (given soft export markets and unfavorable terms-of-trade movements). ${ }^{15}$ The current account corrections have since partially reversed themselves, as the recoveries brought a revival of imports, but by mid-1999 the current accounts of all these countries remained in surplus-reflected in, to varying degrees in different countries, a combination of reserve accumulation and continuing albeit diminished private capital outflows. ${ }^{16}$

It is notable that despite these dramatic macroeconomic events including deep currency depreciations, inflation did not pick up significantly in most of the countries (Figure 6) -in large part reflecting the weakness of domestic demand. The exception is Indonesia, where, as will be discussed, inflation surged briefly into triple digits (at annualized monthly rates). In all the other countries affected, the task of stabilization was made easier by the fact that, due to a combination of policies and circumstances, a vicious cycle of inflation and currency depreciation never started.

A great deal of attention has been paid to the failure of most observers - notably including the $\mathrm{IMF}$ - to predict the macroeconomic developments stemming from the crisis. Initial macroeconomic projections were for a continuation of growth, albeit at slower rates. These projections were revised successively downward with gathering evidence of the severity of the recession. Other market observers, as reflected in consensus forecasts, made similar mistakes, but in principle the Fund's information and analysis should have enabled it to do better. The overoptimism of the Fund's projections reflected, in part, the fact that they are not intended as unconditional forecasts but are part of an overall macroeconomic scenario conditional on the successful implementation of the program. It also reflected the need to agree with the authorities on a common view of the economic situation. Later on, the Fund's projections underestimated the strength of the recovery, and, in the case of Korea and Thailand, have been revised successively upward during the course of 1999 .

\footnotetext{
15 The latter included, for instance, the "semiconductor shock" which began before the crisis, as well as the effects of stiffer regional competition brought on by the crisis itself.

${ }^{16}$ Private capital flows in the first half of 1999 remained negative in Thailand and Indonesia: in Thailand capital outflows have been on a much smaller scale than in 1998, in Indonesia on broadly the same scale. There are signs, however, that private capital flows in Korea have begun to turn around: modest net inflows were recorded in the first quarter of 1999.
} 
Figure 5. Indonesia, Korea, Malaysia, Philippines and Thailand: Net Capital Inflows, March 1997- June 1999

Indonesia

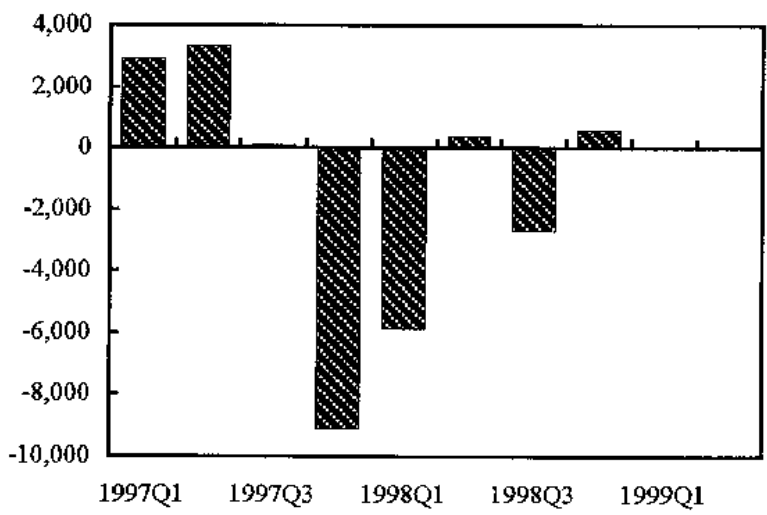

Malaysia

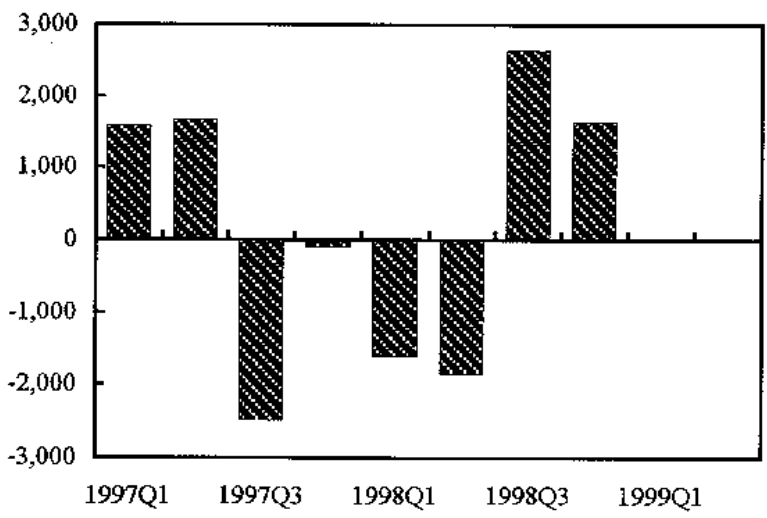

Thailand

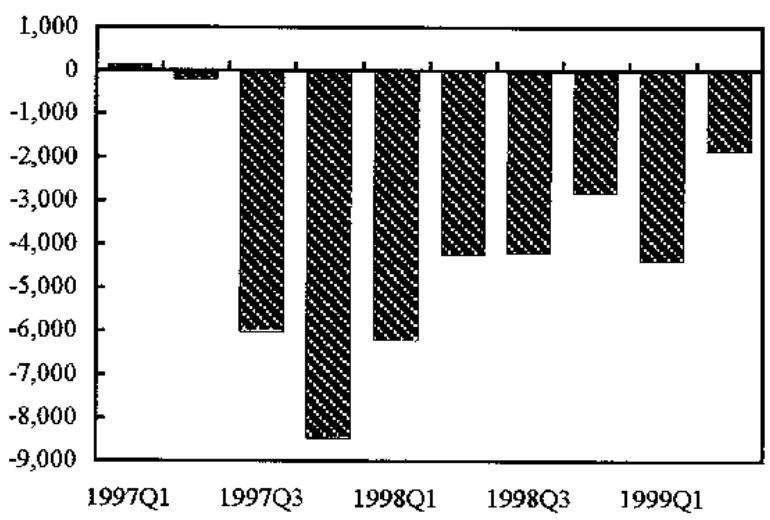

Korea

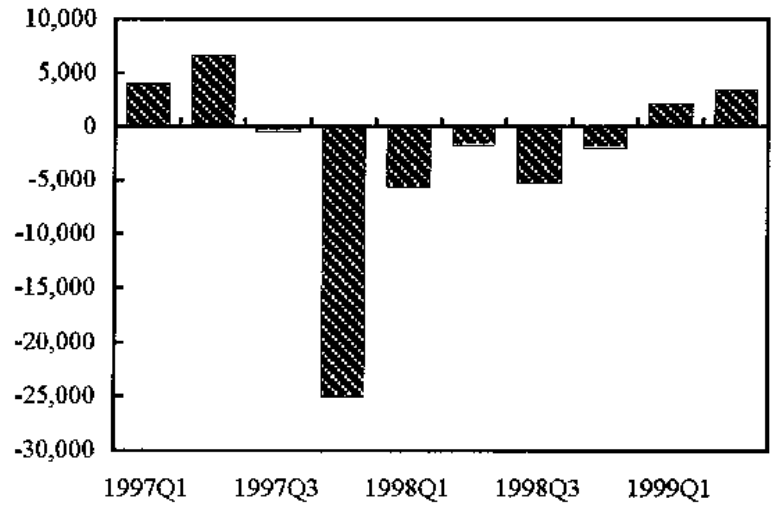

Philippines

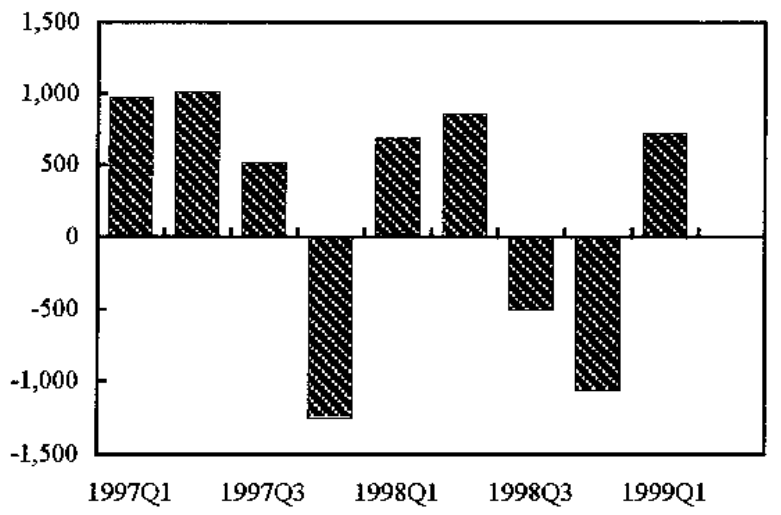

Source: International Monetary Fund, International Financial Statistics and staff estimates. 
Figure 6. Indonesia, Korea, Malaysia, Philippines and Thailand: Inflation, January 1997 - July 1999

Indonesia

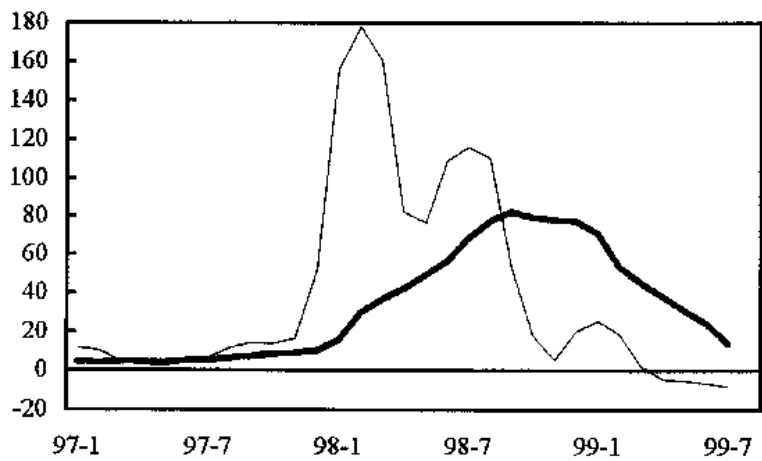

Malaysia

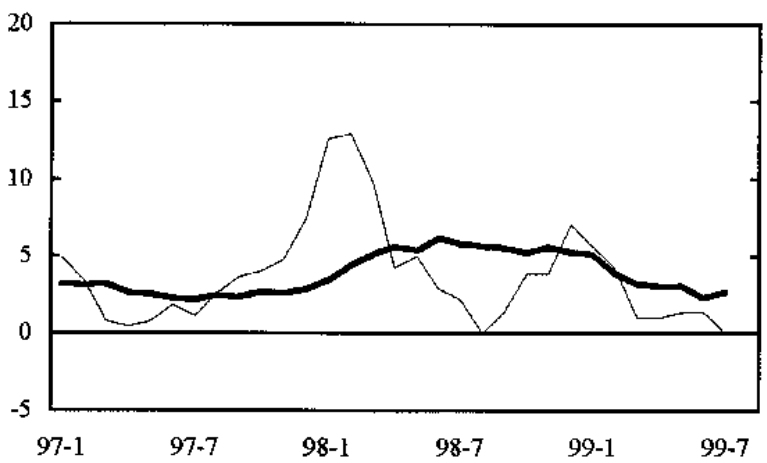

Thailand

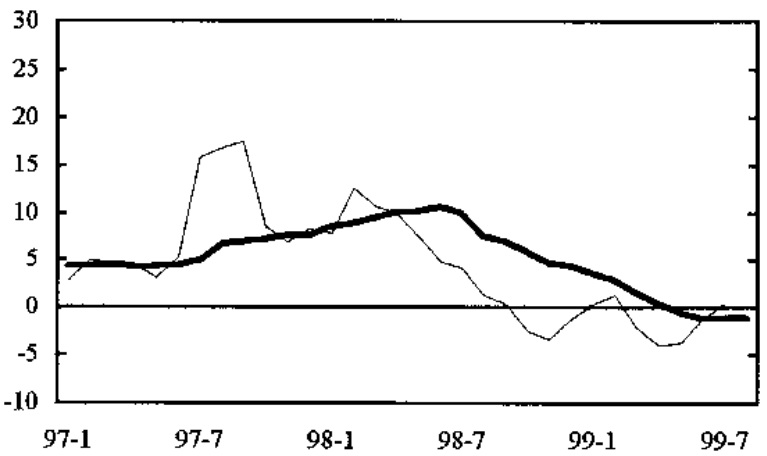

Y Year-on-year rate - Monthly inflation $1 /$

1/ Three-month (centered) moving average of annualized monthly inflation.
Korea

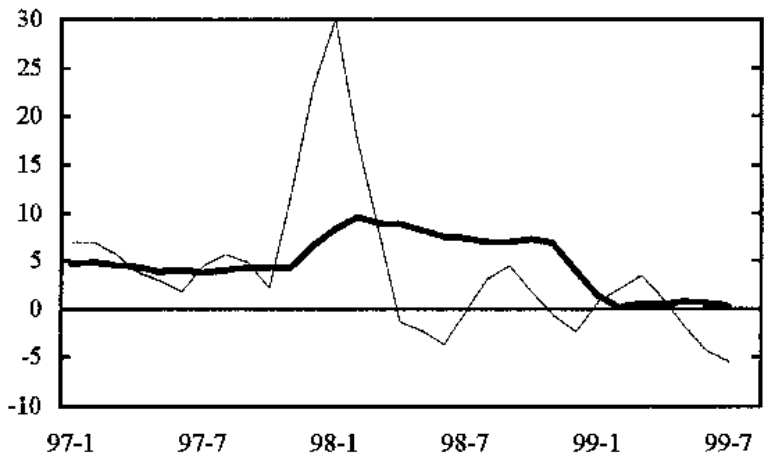

Philippines

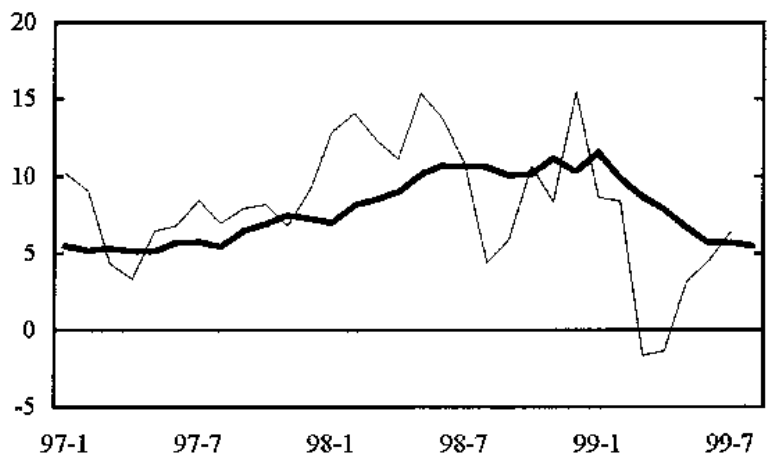


An important question is whether the errors in forecasting the evolution of economic activity during the Asian crisis reflect factors specific to those countries or whether they reflect any more general bias in the Fund's projections. A recent study (Musso and Phillips, 1999) examines program projections for a sample of 69 programs approved between 1992 and 1997. It finds that, although the median error in the Fund's GDP growth forecasts for this entire sample is 0.0 percent, projections have systematically erred on the high side for the subset of countries making heavier use of the Fund's resources-that is, countries such as the Asian crisis countries which also have large access and exposure to capital markets (Box 4). These results may point to a more general problem of predicting the course of economic developments when volatile capital flows are involved.

Unemployment and poverty increased in the three Asian crisis countries, due to the price increases that followed the devaluations combined with declining wages and loss of job opportunities. In Indonesia-where economic developments were exacerbated by political and social unrest and the worst drought seen in years - the percentage of the population living in poverty increased from 11.3 percent in 1996 to 16.7 percent in 1998 . In Korea, urban poverty increased from 9.6 percent to 19.2 percent over the same period. In Thailand, where the middle class was affected the most, poverty increased from 11.4 to 12.9 percent. ${ }^{17}$ In the Philippines, rising unemployment together with drought also had an adverse effect on poverty rates. Private responses cushioned the effects to some extent-including reverse migration of unemployed workers to their rural areas of origin, substitution in consumption bundles, and informal safety nets provided by family networks. With the exception of Indonesia, health and education indicators (such as the incidence of malnutrition and school enrollment and dropout rates) do not appear to have been adversely affected. ${ }^{18}$

\section{PRogram FinanCING}

In considering the strategy of the programs, and the reasons they evolved as they did, special attention must be paid to their financing. This had two components: the official financing packages, and the steps taken to involve private creditors. This section will address each of these components in turn.

${ }^{17}$ Figures are from the World Bank's Global Economic Prospects and the Developing Countries 2000, October 1999, Ch. 2, p. 9 (Table 1).

${ }^{18}$ While of obvious concern, the increase in poverty was less severe than some early projections indicated; see for instance World Bank, 1998. 


\section{Box 4. Program Projections}

Are the Asian programs' large projection errors for GDP and the current account typical, and do program projections systematically err in these same directions? An ongoing study by IMF staff, using internal data for 69 programs approved during 1993-97, suggests that the answers to these questions are "no" and "maybe."

GDP projections. Projection errors of the size found in Asia are infrequent but not without precedent. In particular, a number of programs in transition economies also had GDP fall far short of program projection. Indeed, putting aside the 1997 Asia programs, five of the six largest negative outliers are found in transition economies (the other large negative outlier is the 1995 program in Mexico).

On whether there is a pattern of systematically over-projecting GDP, the evidence is mixed. The median deviation of the GDP growth rate from its projected value is 0.0 percentage points. But while positive errors are about as likely as negative errors, the latter tend to be larger. Thus the distribution of projection errors is skewed to the left, with its middle two quartiles covering a range of -3.4 to +1.8 percentage points. Moreover, the mean error is negative: -0.6 percentage points for non-transition economies, and -1.5 points for transition economies. But these mean errors are sensitive to outliers (e.g., excluding just one transition economy case cuts the mean error in half) and are not statistically significant.

Looking more closely, negative GDP projection errors are more likely in the cases that are probably best known: programs involving larger economies and larger financial arrangements. Within various subsamples constructed to capture such cases, a larger (and statistically significant) negative average projection error is found. In this sense, the negative projection errors in Asia do appear to be part of a more general pattern.

Current account projections. For the current account, errors of the magnitude found in Asia are infrequent but again not unprecedented. The current account balance is indeed more likely to exceed its program projection than to fall short, though the difference is not overwhelming ( 55 percent and 45 percent of programs, respectively). The middle two quartiles of the projection errors, measured in U.S. dollars and then scaled by (PPP-adjusted) GDP, span a range of -0.6 to +1.1 percent; mean and median errors are both about $+1 / 4$ percent, but neither is statistically different from zero. ${ }^{1}$ Programs in large economies, and programs with larger financial arrangements, are associated with larger (positive) projection errors.

In brief, projection errors in the Asia programs were atypical in their large magnitude. However, their combination of GDP over-projection and current account under-projection is not unusual, particularly among "big" programs.

This scaling makes the current account data more comparable across countries and programs. If instead the current account errors were scaled by GDP measured at market or official exchange rates, considerable heteroskedasticity would be introduced. PPP-based GDP is used to avoid such heteroskedasticity induced by temporary exchange rate fluctuations. (Moreover, in this sample, PPPbased GDP is typically about three times larger than GDP measured using market or official exchange rates, reflecting the well-known pattern for developing countries.) 


\section{A. Official financing}

The announced official packages were well beyond the usual size. They assembled money from three sources: the IMF; other multilateral financial institutions (World Bank and Asian Development Bank); and bilaterals contributors (Table 1). However, these packages turned out to provide less financing than met the eye, for several reasons. First, the IMF's financial support is generally phased and conditional: the country gains the right to draw successive tranches as the program proceeds on track. The rationale for such phasing is that it maintains incentives for the authorities to continue implementing the program of policies agreed under the program, countering one form of moral hazard. ${ }^{19}$ In a capital account crisis, however, such phasing may be problematic since the authorities do not have the money up front to counter capital outflows-and indeed, due to conditionality, it is not certain that they will ever have access to this money. A second weakness in official financing in the Asian crisis countries, notably Indonesia and Korea, is that the second lines of defense (SLOD) announced by some bilateral creditors were never disbursed.

In recognition of these issues, the financing was more front-loaded than usual, even at the outset, particularly in the case of Korea where use was made of resources from the newly-established Supplementary Reserve Facility (SRF). The experience of the Asian crisis led to some further reconsideration of the Fund's policies in this area: one example is the provision of a "floating tranche" in Brazil's program concluded in late 1998; another is the establishment in 1999 of the Contingent Credit Line-which, for countries with a strong track record of sound policies, can provide very sizeable resources up front to help forestall or contend with financial "contagion."

The divergence between the large announced packages and much smaller actual disbursements--especially in the early months of the programs-is evident in Table 1. It is notable that the amounts disbursed in the first six months of the program fell far short of what would have been sufficient to redeem the short-term debt maturing during this period. In this light, it is clear that restoring confidence could not rely solely on the mere announcement of the financing packages: the policy content of the programs also needed to play a vital role in this regard. It also suggests, on the other hand, that concerns that the big financing packages would cause moral hazard may have been overdone: official support was far from sufficient to constitute a guarantee of these countries' short-term debts. This is, indeed, confirmed by the fact that private capital continued to exit after the programs were announced. Moreover, large losses were incurred by bond and equity investors.

${ }^{19}$ See, for instance, Guitián 1981. 
Were the programs underfunded--that is, would more ample financing have been needed for the programs to be successful? It is difficult to make a clear case that inadequate financing was a central problem for Thailand or Indonesia. In the case of Thailand, the official financing package included contributions from the Fund, other multilaterals, and bilaterals, and all three components were disbursed pari passu. In addition, the official financing package was complemented by assurances and indications from major private creditors banks. ${ }^{20}$ Indonesia at the beginning of its program still had substantial international reserves. In both countries, the continuing gradual depreciation of the exchange rate once the programs were in place could well be attributable to difficulties with policy implementation rather than underfunding.

In Korea, the situation appears to have been different. Given the very low level of usable reserves and large amounts of short-term debt falling due immediately after approval of the program, rather optimistic assumptions regarding roll-over rates were required to "close" the financing gap in the absence of actual SLOD disbursements. In contrast to Thailand, there were, however, no understandings with private creditors at the start of the program to maintain roll-over rates. As the assumed high roll-over rates failed to materialize, the exchange rate collapsed shortly after the program was approved. At the same time, there were problems in policy implementation which contributed to the deterioration of the situation, but it is debatable whether even perfect policy implementation could have overcome the logic of the process driving toward a funding crisis.

\section{B. Private sector involvement}

The intention with which the programs were designed was that their policy content, together with the official financing provided, would trigger a favorable private market response that would have made full disbursement of the official financing package unnecessary. The programs in most cases were thus constructed on the assumption that private capital would remain voluntarily, making it unnecessary to resort to any direct action to keep capital in place. In the event, a virtuous circle did not materialize and capital continued to exit.

Faced with continuing private capital outflows, all three countries sooner or later resorted to some kind of intervention to limit them. In the case of Thailand, this was done at the start of the program in August 1997, in the form of assurances and indications by Japanese banks that they would maintain their credit lines to their subsidiaries in Thailand. In Korea, no arrangement was made at the outset (in early December) to bail in private capital,

${ }^{20}$ These assurances, involving credit lines of US $\$ 19$ billion of foreign banks resident in Thailand, were received at a meeting with Japanese creditor banks in mid-August 1997. Some uncertainties remained, however, regarding short-term credit lines to Thai banks (US\$11 billion). 
but mounting outflows of short-term capital in the first three weeks of December 1997 brought the country to the brink of default; at that point, an eleventh-hour deal was concluded with major bank creditors to maintain their credit lines to Korea through March 1998; this agreement was broadened at the end of January to a rescheduling of short-term claims by a larger group of bank creditors. In Indonesia, there was also no initial agreement to roll over external debt, but talks with private bank creditors began in February 1998 under the protection of a de facto payments standstill, leading in June to agreement on a framework for restructuring bank and other claims. In Indonesia, bank debts were only the tip of the iceberg, with corporate debt making up the bulk of private external debt; although an agreement on a framework for voluntary restructuring of corporate debts was established in June 1998, to date few corporate debts have actually been restructured under this mechanism.

The experience with private sector involvement in the Asian crisis countries raises some important questions. First, given that all of these countries sooner or later adopted some kind of non-market measures to bail in private creditors, would it not have been better to have anticipated this and done it at the outset? Moreover, should the action to involve private creditors have been more aggressive? The concern at the time of the crisis was that intervention in markets that was seen as too heavy-handed could have exacerbated contagion, reducing the overall financing available to other countries in or on the verge of crisis. But these questions raised by the Asian experience have led to a general exploration of ways of involving the private sector in the resolution and indeed the prevention of financial crises.

The idea of private sector involvement is attractive: in principle, it could reduce the current account adjustment required and possibly also reduce the need for official financing. Such action could also alleviate moral hazard, by imposing losses on those who have made imprudent lending decisions. Looking forward, if such action were taken systematically, it would be reflected in wider interest rate spreads to countries with vulnerabilities such as those underlying the Asian financial crisis, discouraging borrowing by such countries. But there may be tension between these two objectives--keeping financing in place and penalizing imprudent lending: a policy that entails "haircuts" on private creditors could make short-term investors even more skittish, impelling them to exit even more hastily, in anticipation of such measures, while they have the chance. Moreover it is essential to consider the implications of bail-ins as a policy regime - taking account of any change in private behavior that would be likely to result-rather than with regard to isolated episodes. In particular, there is the concern that routinely imposing standstills and capital controls in connection with IMF-supported programs could exacerbate market volatility. (This could also imply that a country's prospect of agreement on a program with the Fund could have a negative rather than a positive effect on market confidence.) The question to ask is not whether a standstill would have helped resolve a particular crisis, but whether a regime in which standstills are liable to be imposed more frequently would be characterized by less or more frequent crises, of lesser or greater severity - as well as what other differences this would make to the functioning of the world economy. (At the same time, if a greater willingness to use such instruments resulted in wider yield spreads to emerging markets, that would not necessarily indicate that these policies were misdirected: those wider spreads could more accurately reflect the underlying risks.) 
Attention has subsequently turned to setting up arrangements beforehand to make it easier to involve private creditors should a crisis materialize. While several important ideas have emerged from this work, it is not yet clear what effect they will have in practice. One is the establishment of credit lines with private creditors that would be activated in the event of a crisis. A second is the incorporation of call options into short-term credits to permit their maturities to be lengthened under specified conditions. ${ }^{21}$ A key question with regard to both of these proposals is the additionality of the funds provided: it is likely that the financial institutions providing the credit lines would hedge themselves in such a way as to maintain their desired overall exposure to the country (or to a region or class of borrowers), defeating the purpose of such arrangements. A third is the incorporation of sharing and qualified majority clauses in bond contracts to facilitate their restructuring in the event of a crisis. While there has been widespread agreement in the official community on the desirability of such clauses, emerging market countries are reluctant to introduce such clauses for fear of the adverse signals it could send: governments do not wish to be seen as trying to make it easier for themselves to default.

The main lesson is that prevention is still by far the best option. None of the ways suggested for forcing private creditors to maintain their exposures in the event of a crisis offers any promise of making a bail-in of private creditors a simple matter, or obviating the damaging effects that forced maturity conversions or haircuts would have on market confidence. Far better to adopt policies that would limit the exposures in the first place.

Sound macroeconomic policies are of course a key aspect of prevention in this regard. Another is sound banking: effective supervision of financial institutions to limit the kind of maturity and currency mismatches that threaten a liquidity crisis and a collapse of the banking system. Another approach that has been receiving increasingly favorable attention is selective capital controls, including Chilean-style minimum deposit requirements on shortterm external borrowing. There is some evidence that such taxes in the Chilean case have permitted a reduction in short-term exposures in the face of an increase in overall capital flows. At the same time, such taxes are liable to circumvention and substitution (e.g. domestic short-term credit may be substituted for external) and have not been fully tested in the case of a crisis; thus the jury is still out.

\section{Monetary Policy}

Monetary policy in the IMF-supported programs in the Asian crisis countries tried to walk a narrow line, seeking to resist downward pressure on exchange rates while avoiding a crippling effect on the real economy. While there was significant tightening, in none of the cases were monetary policies intended to go the limit needed to achieve a fixed target for the exchange rate.

\footnotetext{
${ }^{21}$ For a more detailed discussion of such proposals see International Monetary Fund, 1999.
} 
The design and implementation of monetary policy had to work under significant constraints. High debt-equity ratios in the corporate sectors as well as systemic and structural problems made the financial sector more vulnerable to increases in interest rates; these same factors, together with the prevalence of unhedged foreign currency liabilities, meant that currency depreciation could also have a substantial negative effect on the real economy. Policies also started off at a disadvantage with regard to credibility. This was first of all because of the loss of the exchange rate anchor. The actions of the monetary authorities in the early stages of the programs also undermined credibility: in the period prior to letting exchange rates float, the authorities failed to raise interest rates sufficiently to counteract market expectations ${ }^{22}$ of currency depreciation. Thereafter, there was either initial reluctance to push up interest rates (as in Korea, where the authorities only raised interest rates abruptly in the face of the funding crisis in late December 1997) or stop-go policy as monetary policy was eased again too soon, at the first sign of stabilization. Instances of such premature easing in Indonesia include the relaxation of policies in mid-September 1997 (prior to the IMFsupported program); and the rollback of interest rate increases to pre-crisis levels in November 1997, two weeks after the program was approved. In Thailand, interest rates were lowered prematurely in early August and again in mid-September 1997.

Among the three crisis countries with Fund-supported programs, the course of monetary policy was quite different in Korea and Thailand than in Indonesia. In the first two countries, after initial hesitations, monetary policies were tightened significantly (Figure 6). Exchange rates then stabilized and interest rates gradually declined, so that they were below pre-crisis levels by mid-1998; subsequently, the countries' currencies appreciated substantially again, toward their pre-crisis values. Inflation flickered up, but was well contained.

In Indonesia, in contrast, monetary policy veered widely off course soon after the IMF-supported program started in November 1997, against a background of banking collapse and political turbulence. Basic monetary control was lost as the country's reserves were run down through intervention, the monetary impact of which was more than offset as the central bank poured liquidity into the banking system, ostensibly to stave off its collapse in the face of bank runs (which continued until a blanket guarantee for bank liabilities was announced in January 1998). The result was continuing rapid expansion of nominal money and credit supplies, accommodating dramatic currency depreciation and a surge in inflation. Money and credit expansion slowed but did not turn negative, even in real terms, until later in 1998. It would be highly misleading to interpret Indonesia's high nominal interest rates in late 1997 and the early months of 1998 as an indication of tight policy; rather, they signaled a loss of confidence in the currency as well as in the country's credit-worthiness.

\footnotetext{
${ }^{22}$ Based on surveys of exchange rate forecasts (see Ghosh and Phillips in Lane and others,
} 1999). 
There has been much debate over whether monetary tightening was pushed too far in Asian countries with IMF-supported programs, with damaging effects on the real economy. Much of this debate now seems to have been overtaken by events, since nominal interest rates in Korea and Thailand returned by mid-1998 to below pre-crisis levels, while the level of nominal interest rates in Indonesia clearly reflects many factors other than monetary policy. It is nonetheless useful to re-examine the experience closely with a view to possible lessons for future crises. We shall examine three main issues. First, how tight were monetary policies in these countries? A second, related question is whether there is any basis for the view that monetary tightening led to "credit crunches" in these countries. Third, is there any evidence relevant to the argument sometimes advanced that monetary tightening in this setting was counterproductive? Specifically, is there evidence that high interest rates damaged credit-worthiness to such an extent that its net effect was to exacerbate currency depreciation and inflation?

\section{A. How tight were monetary policies?}

As an initial benchmark for the monetary policy stance, it is important to note that, in all of the countries affected currency depreciations were allowed to go well beyond most estimates of the real exchange rate adjustment required, and the fact that depreciation continued for some time after the initial floating (particularly in Indonesia and Thailand).

Second, it is useful to examine the path of nominal and real interest rates as the crisis unfolded, as shown in Figure 7 . In Indonesia, real overnight and lending rates were consistently negative from late 1997 through August 1998. In contrast, in Korea and Thailand, real rates became very low or negative in the months immediately following the onset of the exchange rate crisis, but thereafter were consistently positive. ${ }^{23}$ In Thailand, real interest rates rose to an average 13 percent in the fourth quarter of 1997 and the first quarter of 1998 , falling to 11 percent in the second quarter of 1998 , and then declined further. In Korea, nominal rates were raised sharply in late 1997, and after a strong but brief surge of inflation, real rates became quite high by historical standards, averaging more than 20 percent in the second quarter of 1998; Korea's nominal interest rates declined quite steadily

\footnotetext{
${ }^{23}$ Figure 6 shows the evolution of two real interest rate measures-the overnight and average lending rate, deflated by an estimate of contemporaneous CPI inflation. Deflating instead by the wholesale price index, perhaps a better indicator of the real interest burden on manufacturers, gives lower real rates (reflecting the larger weight of tradables in wholesale prices). The lending rate shown, from the International Financial Statistics, is not fully comparable across countries (see Figure 7 for details).
} 
Figure 7. Indonesia, Korea, Malaysia, Philippines and Thailand: Nominal and Estimated Real Interest Rates, January 1997- July 1999 1/, $2 /$

Indonesia

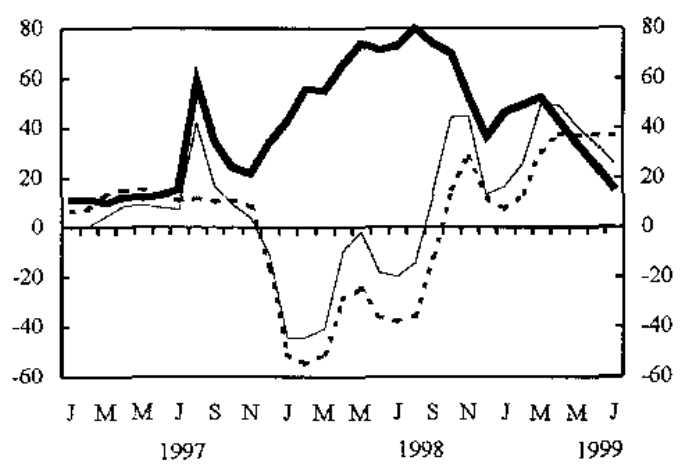

Malaysia

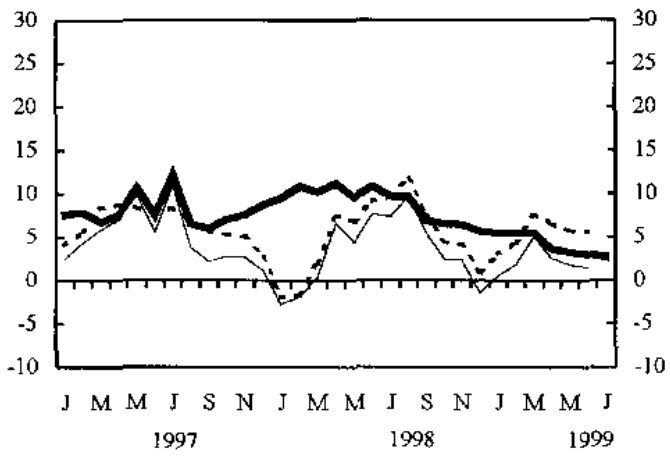

Thailand

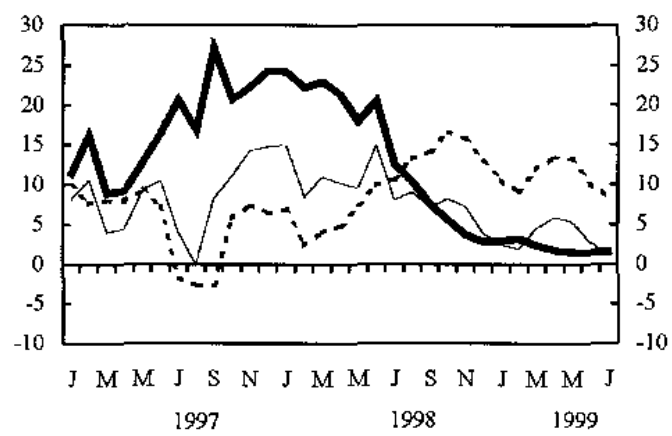

Nominal overnight interbank rate
Korea

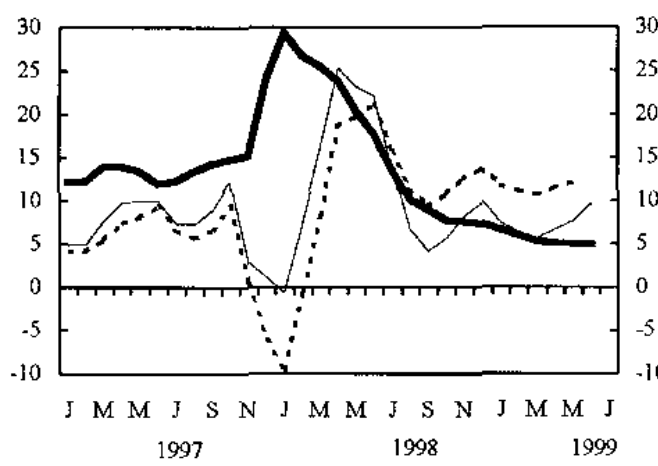

Philippines

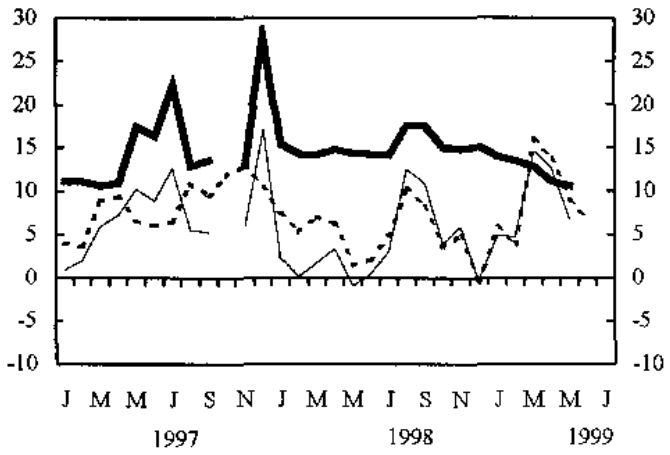


after their January 1998 peak, and by August 1998 were back to near precrisis levels. ${ }^{24}$ In sum, it is not clear that the path of real interest rates itself implied a sustained or crushing burden on activity. Moreover, the initial increases in real interest rates were certainly less aggressive than those seen occasionally in other countries during exchange rate crises or their immediate aftermath. ${ }^{25}$

Interest rates alone cannot tell the whole story, since higher rates may reflect mainly the degree of the problem confronted (in terms of expected inflation/depreciation and the currency risk premium demanded) rather than tightness of liquidity. It is important to ask whether money or credit volumes fell sharply in nominal or real terms ${ }^{26}$. Broad money in Indonesia and Korea, far from severely contracting, continued growing (in both nominal and real terms) in the second half of 1997 and the first half of 1998-(Figures 8 and 9). In Indonesia, rapid monetary expansion was associated with massive liquidity support for a failing banking system. ${ }^{27}$ In Thailand, nominal money did decline slightly in late 1997, and declined in real terms by about 5 percent from mid-1997 through mid-1998.

${ }^{24}$ Ghosh and Phillips, in Lane and others, 1999, also report a measure of ex ante real interest rates, based on an inflation forecasting model: the implied ex ante real interest rates are somewhat lower for Korea and Thailand.

${ }^{25}$ See Lane and others, 1999, Box 9.

${ }^{26}$ Nominal money and credit growth are generally more relevant as a measure of the monetary policy stance, as real money and credit often contracts substantially when loose monetary policy results in high inflation. We consider real as well as nominal money and credit here to ensure that adequate weight is given to the possibility that tightening was excessive.

${ }^{27}$ For Korea, where inflation was minimal and household saving increased during 1998, the growth of real balances may reflect an increase in money demand. In Indonesia, however, it is more likely related to lags in the money-inflation relationship. 
Figure 8. Indonesia, Korea, Malaysia, Philippines and Thailand: Money and Domestic Credit July 1996 - December $19981 / 2 /$
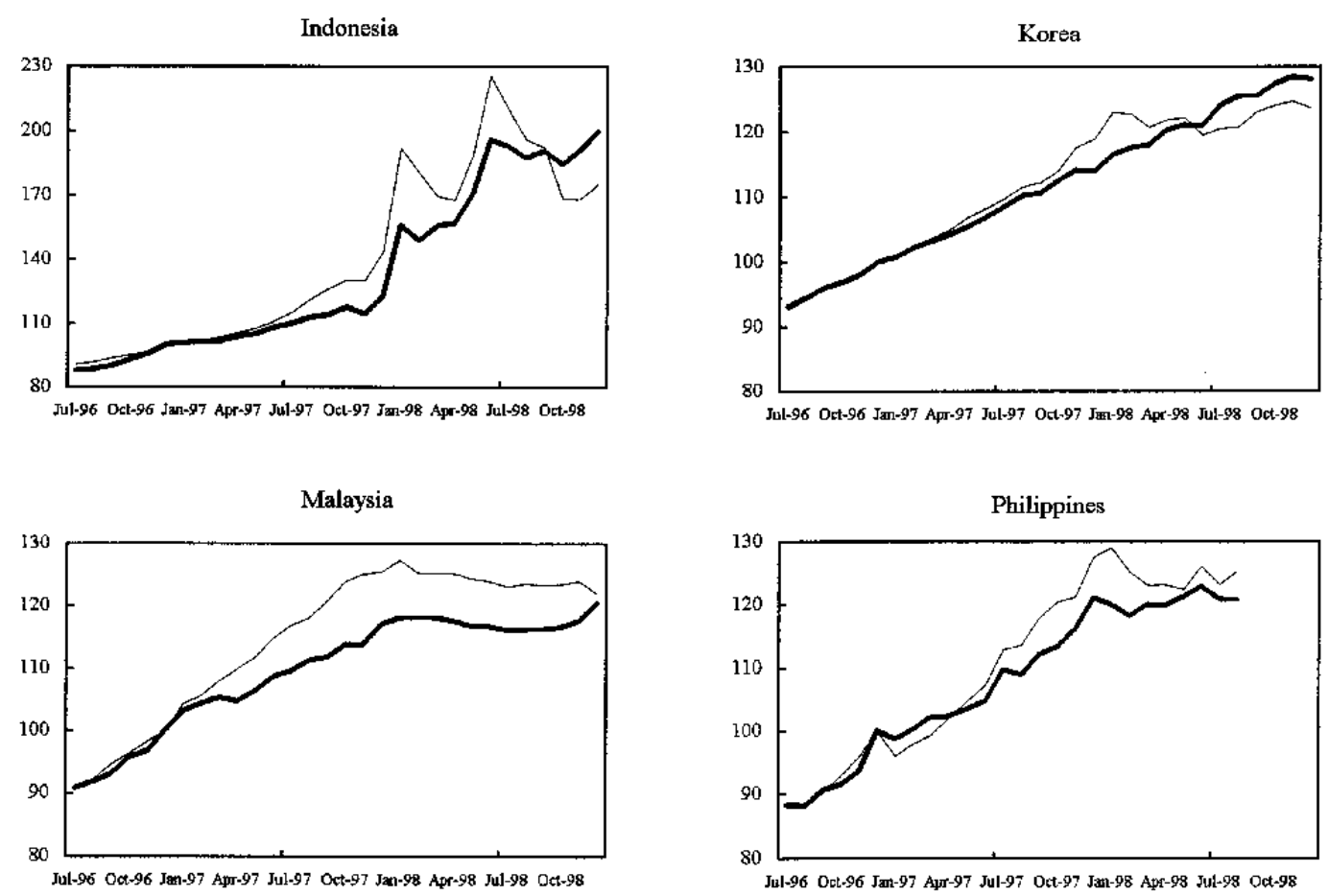

Thailand

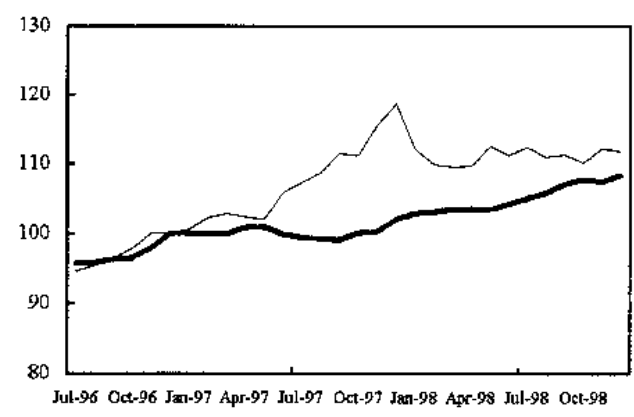

\begin{tabular}{|lll|}
\hline & Money & Domestic credit \\
\hline
\end{tabular}

Sources: Data provided by the authorities; and IMF staff estimates.

1/ Broad money and domestic credit at actual exchange rates, deflated by the Consumer price index.

2/ Index, Dec $1996=100$ 
Figure 9. Indonesia, Korea, Malaysia, Philippines and Thailand: Money and Domestic Credit in Real Terms, July 1996 - December 1998 1/2/
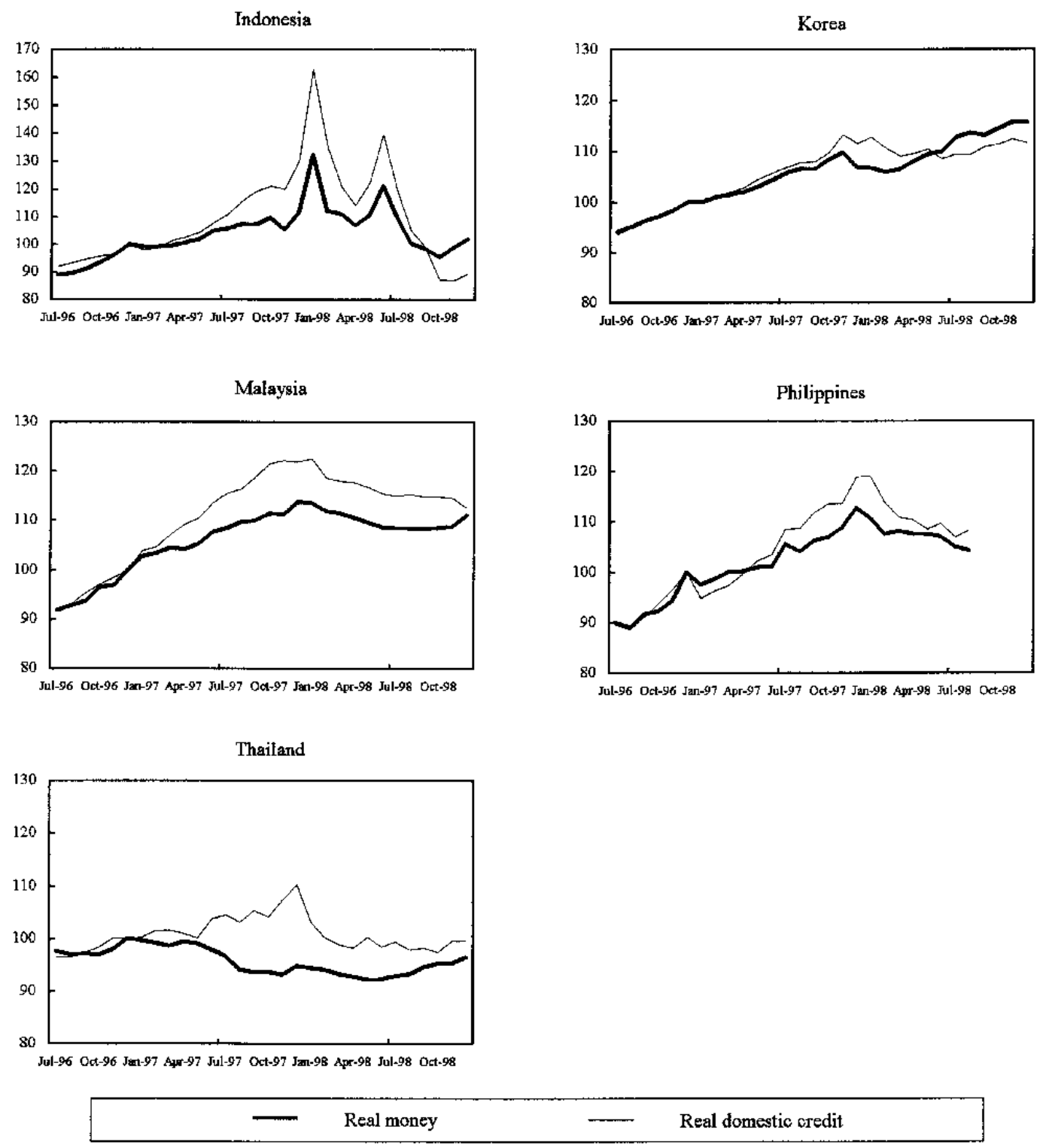

Sources: Data providcd by the authorities; and IMFi staff estimates.

1/ Broad money and domestic credit at actual exchange rales, deflated by the Consumer price index.

2/ Index, Deo $1996 \div 100$ 
There is also little evidence of tightening of nominal or real credit during the second half of 1997. The measured stock of credit grew in real terms at annualized rates ranging from 13 percent in Korea, to 15 percent in Thailand, to almost 40 percent in Indonesia. ${ }^{28}$ Credit growth decelerated in all three countries in the first half of 1998. In Indonesia, credit underwent severe fluctuations, with a trend of rapid expansion through mid-1998, which was partly reversed in the latter part of the year. In Korea, credit leveled off in nominal terms (and turned slightly negative in real terms) in the first few months of 1998; while in Thailand both nominal and real credit declined from a sharp peak at the beginning of 1997.

The slower growth rates of money and credit, although not inconsequential, do not appear draconian. Despite dire warnings that tightening monetary policies in the midst of a banking crisis would trigger an implosion of liquidity, there was certainly no repeat of the Great Contraction. ${ }^{29}$ Nor is the degree of tightening unusual when considered against the recent experience of other countries facing exchange rate crises. ${ }^{30}$

What impact did this monetary tightening have on the economies of the Asian crisis countries? Some illustrative calculations, based on estimated impulse response functions of real GDP growth to a given deceleration of the growth of real money, may give a rough idea. $^{31}$ These calculations suggest that for Korea and Thailand, the estimated effects of monetary tightening could account for less than one-fourth of the negative swing in GDP growth rates from 1997 to 1998 , and a very small part of the deceleration in Indonesia. (The actual effects could be smaller, since the technique attributes all money-growth correlation to money's influence on growth. On the other hand, the historical relationships examined are unlikely to capture the banking-related sensitivity of output.)

${ }^{28}$ One caveat is that some of the measured increases in credit reflected valuation changes affecting foreign-currency-denominated credit-a factor particularly important in Indonesia. The measure presented includes these valuation changes (consistent with the treatment of the effects of inflation) as they nonetheless affect the amount of real financing or real liquidity being provided to the economy. An alternative approach, based on credit flows, gives a different month-to-month pattern but does not greatly alter the overall picture.

${ }^{29}$ In the classic example of the United States during the Great Depression, the nominal money stock fell by one-third (Friedman and Schwartz, 1963, Chapter 7 ("The Great Contraction"); and Lebergott, 1984).

${ }^{30}$ See Lane and others, 1999 , Table 3, for a basic comparison against money and credit developments during three other episodes - the Czech Republic in May 1997, Mexico in December 1994, and Sweden in November 1992.

${ }^{31}$ See Lane and others, 1999, Appendix 6.1, for details. 
Thus, available monetary indicators tend to contradict the view that monetary policy was tightened drastically in these countries and that this tightening was a major reason for the economic slowdown in the Asian crisis countries. Indeed, events in Indonesia display a breakdown of monetary control rather than severe tightening.

\section{B. Was there a credit crunch?}

How can the evidence on indicators of monetary policy be reconciled with widespread perceptions of a "credit crunch" in these countries? While there was clearly a sharp fall in external finance available, considerable debate has centered on whether domestic credit conditions tightened excessively. Research on this topic is still at an early stage, and both the results and their interpretation are very much mixed (Box 5). In particular, it is difficult to distinguish to what extent credit market dislocations were attributable to inappropriately tight monetary policy and excessively rapid introduction of higher prudential standards, as alleged by critics, and to what extent it was due to the heightened perception of riskiness and loss of collateral resulting from the insolvency associated with the crisis itself.

Clearly, the aggregate data cannot capture shifts in credit allocation among different borrowers, in the face of widespread bankruptcies and an increased preoccupation of financial institutions with credit risk (associated in part with the tightening of prudential regulations). It would not be surprising if, in this environment, many borrowers that previously had access to credit (especially small and medium-sized enterprises) found themselves unable to obtain financing. The counterpart of this cutoff of access to credit could be an increased share of credit going to capitalize interest on loans to companies perceived as more creditworthy (especially to larger companies, as is reported to be the case in Korea). Disruptions in credit markets are of concern although not uncommon in such circumstances. ${ }^{32}$ To the extent that they reflect structural problems in credit allocationproblems that are unresolved even as the macroeconomic consequences of the crisis have dwindled - the main solution is to move ahead with the needed restructuring of financial systems and workout of corporate debt.

\footnotetext{
${ }^{32}$ Moreover, credit crunches have sometimes occurred in the absence of either a currency crisis or severe monetary policy tightening, for example, in the United States in 1990-91, the episode that inspired the recent literature on the subject.
} 


\section{Box 5. Was There a Credit Crunch?}

There has been much discussion about a "credit crunch" in the East Asian economies. While there was clearly a sharp fall in external finance available, the debate has centered on whether domestic credit conditions tightened significantly, and perhaps excessively.

The term credit crunch is perhaps best understood as a situation in which, at prevailing interest rates, there is an unsatisfied excess demand for credit (or perhaps a sudden increase in such excess demand). In the present context, however, the term also has been used more loosely to refer to tight credit conditions. Research on this topic is still at an early stage, and both the results and their interpretation are very much mixed. This box briefly reviews some recent work on this issue.

- $\quad$ Dollar and Hallward-Driemeier (1998) conducted a survey of 1,200 Thai manufacturing firms in late 1997 and early 1998. Asked to rank the causes of the output decline (out of four possibilities), the most important factor cited by both exporters and nonexporters was the effect of the exchange rate depreciation on input costs, followed by weak demand. High cost of capital was ranked third, and lack of access to credit ranked last.

- Domaç and Ferri (1998) examine the relationship in Korea between increases in the spread between bank lending rates and treasury bond rates and industrial production. In general, they find Granger causality from increases in the spread to subsequent declines in industrial production, with a 1 percentage point increase in the bank lending spread is associated with a 1.4 percent decline in industrial production ( 1.7 percent in the case of small- and medium-scale enterprises). The paper concludes that wider spreads and higher interest rates could account for a fall in industrial production of as much as 5-10 percent.

While such evidence is suggestive, there are issues in its interpretation. Most important, the estimation period covers the early 1990s through February 1998. Since the variables examined fluctuated relatively little in the sample period until the crisis periodwhen there was a sharp fall in production and a rise in interest rates - and since no allowance is made for other factors influencing production (such as falling demand or currency depreciation - as the Dollar and Hallward-Driemeier evidence suggests), the effect attributed to larger spreads and higher interest rates is necessarily substantial. Moreover, Granger causality says little about economic causality-especially in this context. If output is expected to fall (for any reason), the perceived riskiness of lending to the corporate sector may increase, and this should be reflected in an immediate increase in spreads and interest rates: Granger causality here could reflect nothing more than financial variables moving more quickly than the real economy. 


\begin{abstract}
On whether priority should have been given to stabilizing the exchange rate or lowering interest rates, Claessens, Djankov, and Ferri (1998) assess the impact of the currency and interest rate shocks (between early 1997 and September 1998) on the liquidity and the solvency of a sample of East Asian firms. They define a firm to be illiquid when earnings (before income tax but after depreciation) fall short of debt service; and insolvent when total liabilities at the new exchange and interest rates exceed end-1996 equity. Given the magnitude of the exchange rate movements, they find that the exchange rate shock alone was sufficient to drive almost two-thirds of Indonesian firms, 20 percent of Korean firms, and 10 percent of Thai firms (in their sample) into insolvency-and to drive 72 percent, 38 percent, and 55 percent, respectively, into illiquidity. The effect of interest rates is smaller, with the interest rate shock driving about 2-5 percent of firms in each of the countries into insolvency, and 15 to 25 percent into illiquidity. (The paper also notes, however, that about 35 percent of firms in these countries are solvent but illiquid-suggesting the importance of restoring credit flows rapidly.) The results are interesting, but without exact knowledge of the feasible trade-off between higher interest rates and a smaller depreciation, the direct operational implications are not clear.

- Finally, Ghosh and Ghosh (1998) examine whether there was a credit crunch-in the sense that the (often low or negative) real interest rates may not have cleared the credit market and there was quantity rationing. They apply an explicit disequilibrium framework, and estimate credit supply and demand functions. In Indonesia, they find some evidence of a credit crunch in late 1997 as the banking crisis deepened. Thereafter, credit demand also fell sharply, so supply was no longer the binding constraint. In Korea and Thailand, real credit supply did decrease in late 1997 and early 1998, but the fall in real credit demand was sharper, so credit supply was not the constraining factor. (These results are thus consistent with the Dollar and Hallward-Driemeier (1998) findings.
\end{abstract}

There are two important caveats to their results. First, rising real interest rates themselves may have contributed to corporate sector distress, quite aside from any credit crunch. Second, the results pertain to the aggregate economy-at a microeconomic level, there may have been (otherwise creditworthy) firms, especially small and medium-scale enterprises, that were denied credit in an environment of informational asymmetries, and as banks strove to improve loan portfolios and meet capital adequacy standards.

\title{
C. Was monetary tightening counterproductive?
}

This brings us to the final question: was monetary tightening actually counterproductive, in view of the weakness of the financial and corporate sectors? This possibility stems from the view that monetary tightening may have an adverse effect on the solvency of the banks and corporations borrowing in international markets. If this adverse effect is large enough, it may even outweigh the direct effect of the monetary tightening. 
Under these circumstances, monetary tightening would, on balance, undermine confidence and thus further weaken exchange rates. (It would therefore follow that monetary tightening could also increase inflation). This possibility can be viewed as analogous to the "unpleasant monetarist arithmetic" characterized by Sargent and Wallace (1981), but working via the financial system rather than the fiscal position. The theoretical possibility that policies could have such perverse effects has been argued cogently, among others, by Furman and Stiglitz (1999).

The key question is whether this theoretical proposition is likely to have been relevant under the conditions of the East Asian crisis. While a number of papers have tried to examine this issue empirically (see Box 6), this is not a question that lends itself very easily to econometric analysis. Figure 10 shows why.

Consider the case of Thailand (bottom panel). Until May 1997, interest rates fluctuated between 8 and 15 percent, while the exchange rate remained virtually constant (reflecting a de facto fix against the dollar, despite the formal peg to a basket of currencies). From May 1997 till September 1997, higher interest rates were generally accompanied by continued exchange rate depreciation (the "Stiglitz" effect), but from September 1997 to December 1997, interest rates fell and the exchange rate depreciated (the "orthodox" relationship). Interest rates then rose (with continued exchange rate depreciation) till January 1998, and from January until March 1998, higher interest rates were associated with an exchange rate appreciation. Finally, since June 1998, interest rates have fallen steadily, with apparently few ill effects on the exchange rate. 
Box 6. Episodic Evidence on the Interest Rate-Exchange Rate Relationship

A number of recent studies have tried to assess empirically whether higher interest rates are useful in supporting the exchange rate (that is, the "traditional" effect) or whether they instead have an opposite, "perverse" effect. Rather than examining the long-run relationship between monetary policy and the exchange rate, these studies focus on patterns inside selected short episodes.

The results of these studies are inconclusive and indeed quite mixed. In general, they fail to find overwhelming evidence of the traditional effect - though this is not surprising, given the inherent policy endogeneity problem (that is, interest rates are likely to be raised precisely during episodes of currency depreciation, as both variables respond to shifts in market sentiment). On the other hand, neither is there a clear pattern of evidence across studies of a perverse effect of interest rate policy.

Furman and Stiglitz (1998) identify a set of 13 episodes, in nine emerging markets, of "temporarily high" interest rates (episodes in which interest rates rose by more than 10 percentage points for at least five days, then fell back). Using a simple regression analysis, they find that both the magnitude and duration of such interest rate hikes are associated with exchange rate depreciation. While Furman and Stiglitz note that this evidence is not definitive, and that its interpretation is fraught with difficulties concerning endogeneity, they conclude that it at least questions the usefulness of raising interest rates.

Kraay (1998) focuses instead on episodes of speculative attacks on currencies and uses a more sophisticated and complex methodology. He identifies a set of 121 attacks that were successful, in the sense that there was an uncharacteristically large monthly depreciation; he also identifies (with greater inherent difficulty) a set of 192 unsuccessful attacks. The essential finding is that increases in central bank discount rates are neither necessary nor sufficient for staving off a speculative attack. Indeed, no relationship is found between central bank discount policy and the success or failure of speculative attacks. When Kraay tries to control for the endogeneity of interest rate policy, the results are similar, although, as he notes, they are preliminary and could reflect the difficulty of specifying appropriate instrumental variables to control for policy endogeneity.

Goldfajn and Gupta (1998) ask a somewhat different question, one probably more relevant for the East Asian countries during their IMF-supported programs. They consider cases following an exchange rate crisis in which the real exchange rate has become clearly undervalued, so that considerable real appreciation is likely to follow. They then study whether tighter monetary policies - in terms of higher-than-average real interest rates - are associated with the corrective real appreciation occurring mainly through currency appreciation rather than through higher inflation. 
In general, Goldfajn and Gupta find that tight monetary policy does raise the probability of "success"; that is, achieving the corrective real appreciation via currency appreciation. However, when the sample is restricted to cases where the banking sector is fragile, tight monetary policy seems to reduce the probability of success (though as the authors note, this latter result is based on very few cases and is not robust).

Goldfajn and Baig (1998), rather than defining and identifying crisis episodes from a broad sample of countries, focus on the very recent experience of five Asian countries, from mid-1997 through May 1998. Using daily data, they analyze the relationship between nominal interest rates and nominal exchange rates during the recent Asian crisis. A vector autoregression does not find a significant relationship - in either direction-for any of the five Asian countries. On the other hand, a panel regression using changes in interest rates and exchange rates yields a traditionally-signed coefficient over all the sample spans examined, though this is statistically significant only in some subperiods. Country-by-country regressions find a significant traditionally-signed coefficient in some periods for Indonesia, Korea, and the Philippines (the only significant coefficient with the opposite sign is found for Malaysia, and this in one subperiod only). Goldfajn and Baig thus conclude that their study finds no evidence that higher interest rates lead to weaker exchange rates; if anything, there are periods where higher rates lead to stronger exchange rates

Gould and Kamin (1999) examine the link between exchange rates and interest rates using weekly data. They attempt to control explicitly for the endogeneity of interest rates by entering variables proxying for the risk premia in the regression. The paper finds no effect of interest rates on exchange rates in either direction, which the authors suggest may be due to the difficulty of identifying such an impact in weekly data, especially in a short sample.

Tanner (1999) examines the relationship between domestic credit growth and exchange market pressure (i.e., the sum of exchange rate depreciation and reserve outflows scaled by base money). Using data for Brazil, Chile, Mexico, Indonesia, Korea, and Thailand, he finds that contractionary monetary policy tends to reduce exchange market pressure, consistent with the traditional view. 
Figure 10: Interest Rates and Exchange Rates in Selected Asian Crisis Countries
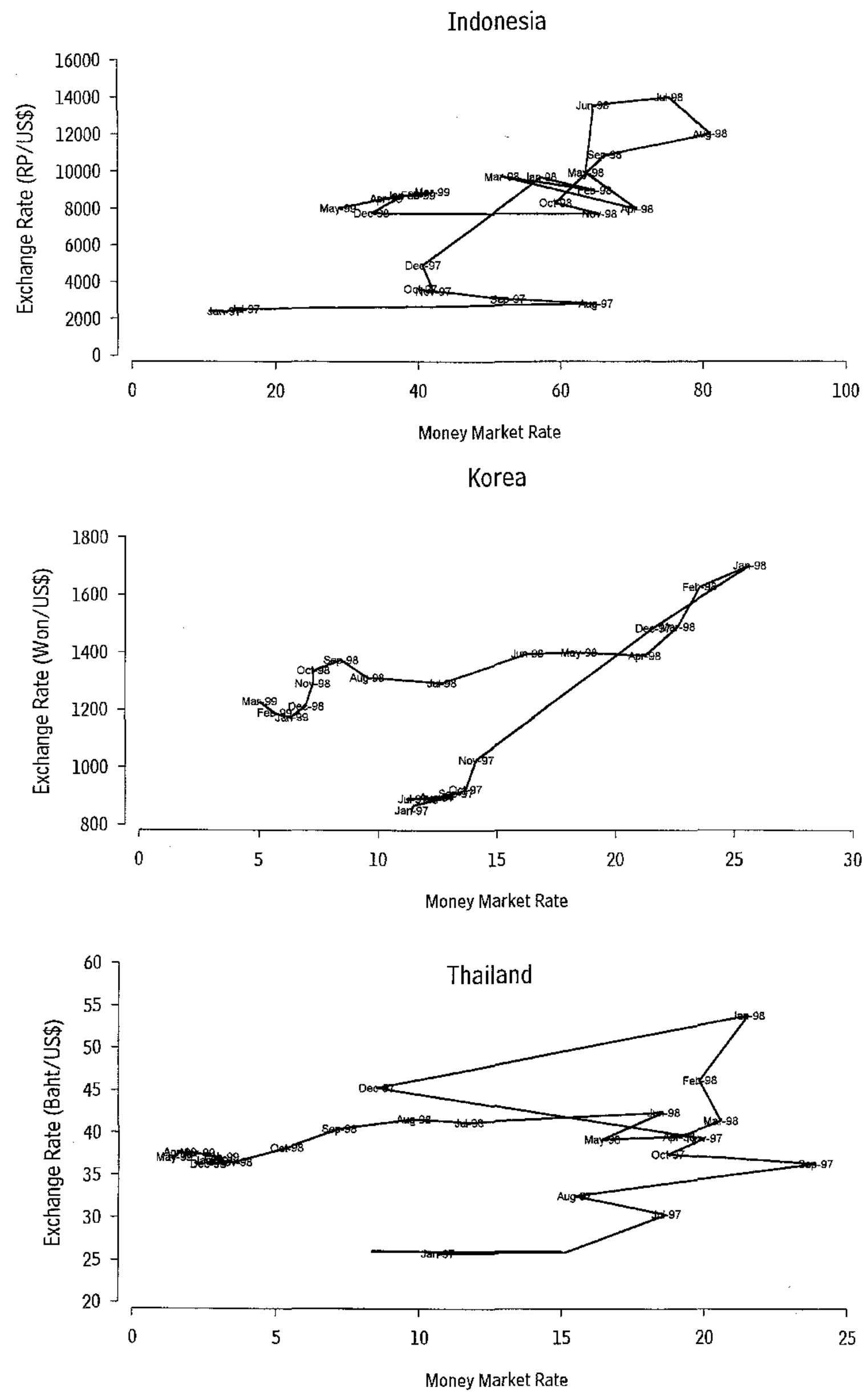
It is hard to know what to make of all this-let alone know how sophisticated econometrics would interpret the time series behavior: neither the orthodox school ("tight money appreciates the exchange rate") nor the Stiglitz school ("high interest rates depreciate the exchange rate") would receive unequivocal support. A quick check of Korea or Indonesia likewise suggests periods during which interest rate and exchange rate movements were positively correlated, but also periods when higher interest rates were associated with exchange rate appreciations.

The underlying problem is that it is impossible to tell what is the counterfactual, and of course, many factors other than interest rates-such as the availability of official external financing, debt deals with creditors, and political uncertainty-were impinging on the exchange rate as well.

A further difficulty is that interest rates often reflect risk premia and expected depreciation and inflation and do not provide a very clear indication of the monetary stance of the country. Perhaps the starkest example of this is Indonesia in the first half of 1998 , where nominal interest rates rose to 60 percent - by far the highest of any of the Asian countries - at a time when the money supply was increasing at a monthly rate of 30 percent!

Do the monetary aggregates tell a clearer story? Figure 11 shows the corresponding time plots for the exchange rate and broad money supplies in these countries. For Thailand and Indonesia, the orthodox relationship-with greater monetary expansion associated with an exchange rate depreciation-comes through clearly. For Korea, the time plot is more difficult to interpret: the exchange rate clearly overshot in late 1997, and then appreciated back, but again, taking the period as a whole, looser monetary policy is associated with an exchange rate depreciation.

The (comparatively) stronger relationship between monetary aggregates and the exchange rate suggests an alternative approach to studying whether higher interest rates contributed to an exchange rate weakening via the risk premium, based on an explicit monetary model of exchange rate determination. This is the tack taken by Basurto and Ghosh (1999) who first model the exchange rate dynamics using a standard monetary model, and then ask whether higher real interest rates contributed to (or at least are correlated with) a weakening of the exchange rate. Their results, summarized in Box 7, suggest not. Indeed, though the model generally fits well for each of the three countries, the effect of higher real interest rates on the risk premium is found to be insignificantly different from zero.

Ultimately, it is probably impossible for either school to prove its case conclusively. On balance, however, there seems to be little evidence that monetary conditions in East Asia were tightened to the point of having a counter-productive effect on the exchange rate. 
Figure 11: Broad Money and Exchange Rates in Selected Asian Crisis Countries
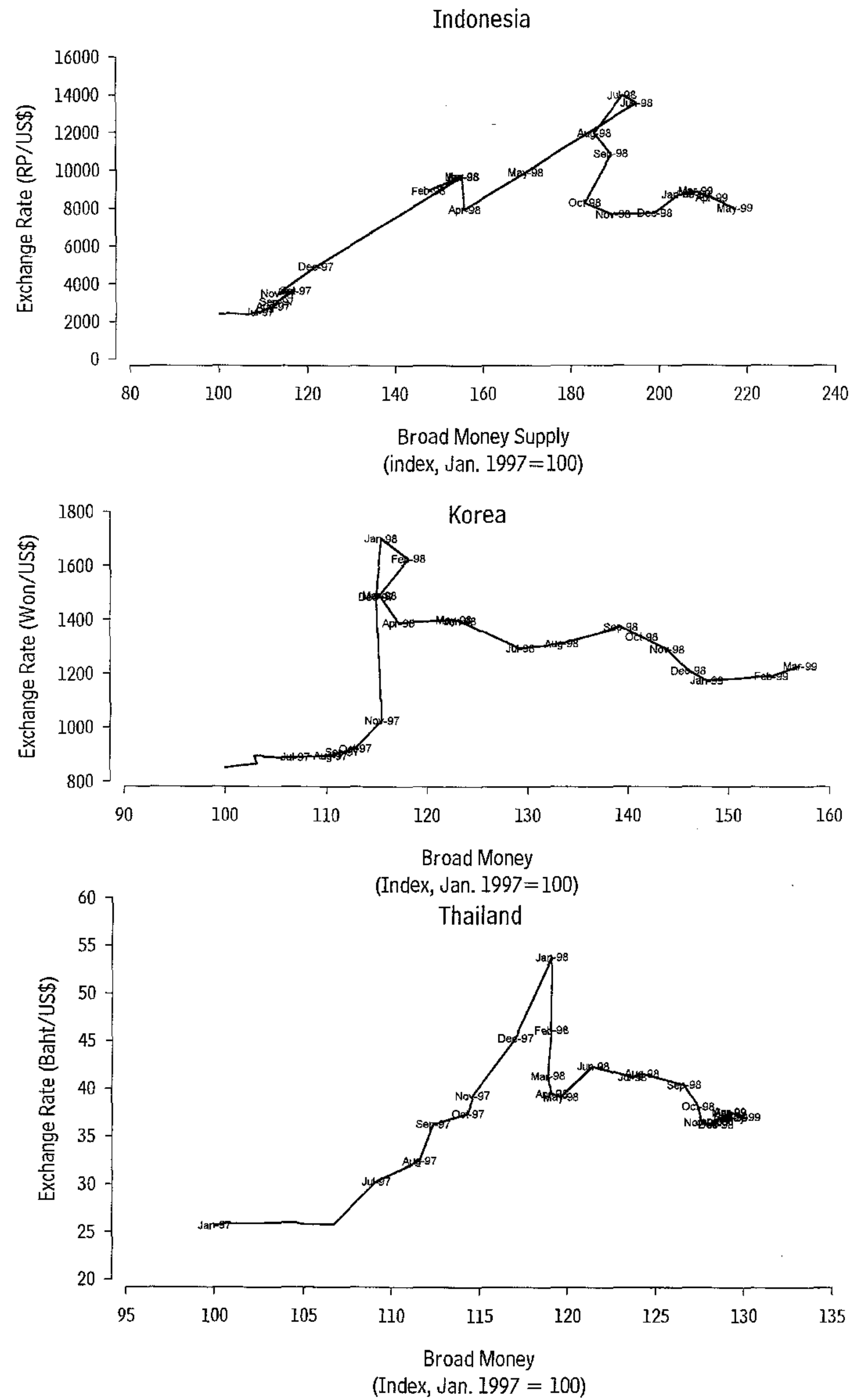


\section{Box 7: Did High Interest Rates Contribute to Weakening of the Exchange Rate?}

Basurto and Ghosh (1999) examine the effect of higher real interest rates on the exchange rate in an explicit monetary model of exchange rate determination. The model consists of three basic building blocks. Real money demand depends positively on income and negatively on the nominal interest rate:

$$
m_{t}-p_{t}=\alpha y_{t}-\beta i_{t}
$$

where $m$ is the log of money, $p$ the log of the domestic price index, $y$ the log of output, and $i$ the domestic interest rate. (Asterisks denote the corresponding values in the foreign country.) Domestic and foreign interest rates are linked by an interest parity condition:

$$
i_{t}=i_{t}^{*}+s_{t+1}^{e}-s_{t}+\pi_{t}
$$

where $s$ is the exchange rate (an increase in $s$ is a depreciation), and $\pi$ the risk premium. Finally, the real exchange rate $w_{t}$ is defined by:

$$
p_{t}=p_{t}^{*}+s_{t}+v_{t}
$$

Solving forward for the (first-difference of the) nominal exchange rate yields:

$$
\Delta s_{t}=\frac{1}{1+\beta} \sum_{j=0}^{\infty}\left(\frac{\beta}{1+\beta}\right)^{j} E_{t}\left\{\Delta x_{t+j}+\Delta \pi_{i+j} \mid \Omega_{t}\right\}
$$

where $x_{t+j}=m_{t+j}-m^{*}{ }_{t+j}-v_{t+j}-\alpha\left(y_{t+j}-y^{*}{ }_{t+j}\right)$.

It is useful to define the theoretical exchange rate (excluding the risk-premium) by:

$$
\Delta s_{t}^{e}=\frac{1}{1+\beta} \sum_{j=0}^{\infty}\left(\frac{\beta}{1+\beta}\right)^{j} E_{t}\left\{\Delta x_{t+j} \mid \Omega_{t}\right\}
$$

then, conceptually, the test consists of correlating the difference between $\Delta s-\Delta s^{e}$ to the variable of interest, $w_{t}$, such as the level of real interest rates (as suggested by Stiglitz). 
The actual test is somewhat different, and follows Campbell and Shiller (1987) who study such present value relations extensively in a somewhat different context, and Ghosh (1992) for the monetary model of the exchange rate. First a VAR is estimated in $z=\left\{\Delta x_{t}\right.$, $\left.\Delta \mathrm{s}_{\mathrm{t}}, \Delta \mathrm{w}_{\mathrm{t}}\right\}: \mathrm{z}_{\mathrm{t}}=\Phi \mathrm{z}_{\mathrm{t}-1}+\varepsilon_{\mathrm{t}}$ then :

$$
\Delta s_{t}^{e}=\left[\begin{array}{lll}
1 & 0 & 0
\end{array}\right]^{\prime} \frac{1}{1+\beta}\left(1-\frac{\beta}{1+\beta} \Phi\right)^{-1}\left(\begin{array}{l}
\Delta x_{t} \\
\Delta s_{t} \\
\Delta w_{t}
\end{array}\right)
$$

Writing out this equation explicitly yields: $\Delta s_{t}^{e}=\Gamma_{1} \Delta x_{t}+\Gamma_{2} \Delta s_{t}-\Gamma_{3} \Delta w_{t}$. Under the null hypothesis that the pure monetary model (i.e. without the risk premium) is correct, $\Gamma_{1}=$ $0, \Gamma_{2}=1$, and $\Gamma_{3}=0$. Under the alternative, that $w_{t}$ is correlated with a currency depreciation, $\Gamma_{3}>0$. Finally, the overall fit of the model may be assessed by comparing the fitted and actual exchange rates.

The model is estimated over the period 1990:2-1998:12 for Indonesia, Korea, and Thailand. On the whole, the model fits relatively well, with the correlation between the fitted and actual exchange rate ranging from +0.92 to +0.97 . Turning to the risk premium, there is little evidence that higher real interest rates contributed to depreciation of the exchange rate. Ghosh and Basurto report two sets of results: first, with the real lending rate as the determinant of the risk-premium, and second, including a simple contagion variable as well:

\begin{tabular}{llll}
\hline & Indonesia & Korea & Thailand \\
\hline$\Gamma_{3}$ coef. & 0.17 & 0.25 & -0.14 \\
t-stat. & 1.50 & 1.90 & 1.53 \\
With contagion variable & & & \\
$\Gamma_{3}$ coef. & 0.04 & 0.20 & -0.13 \\
$t$-stat. & 0.22 & 1.47 & 1.36 \\
\hline
\end{tabular}

For Thailand, the estimated coefficient is actually negative, and including the contagion variable, for none of the countries can the null hypothesis - that higher real interest rates (controlling for the monetary stance) do not cause an exchange rate depreciation-be rejected. That is, there is little evidence that tighter monetary policy was counterproductive in stabilizing the exchange rate. 
There is therefore still no convincing evidence that shows that monetary tightening was counterproductive. In contrast, policy, albeit only after some period, achieved its basic objective of avoiding a depreciation/inflation spiral in both Korea and Thailand-without necessitating persistently and exceptionally high real interest rates, and without causing a collapse of nominal, or even real, money or credit volumes. This is not to deny, of course, that monetary tightening had a cost for the real economy, but the alternative could well have been more costly.

\section{Fiscal Policy}

The role of fiscal policy in the Asian crisis countries was not at all typical. In most IMF-supported programs, fiscal policy is at the very core: most often, the main factor underlying a country's need for IMF support is the monetization of fiscal imbalances which has resulted in unsustainable current account imbalances and/or domestic inflation. In contrast, in the Asian crisis countries, except in Thailand, conventionally measured fiscal imbalances were not a very important element of the initial problem. Initial fiscal policies accordingly aimed mainly at holding the line: for the most part, the goal was to make room for the estimated carrying costs of bank restructuring without increasing the overall deficit, as well as contributing to the needed current account adjustment ${ }^{33}$ In the case of Thailand, there was also the aim of counteracting an increase in the fiscal deficit that had occurred in the previous year.

The initial setting of fiscal policy was predicated on the assumption-incorrect, as it turned out - that economic growth would continue, albeit at a slower rate, despite the crisis. These overly-optimistic growth projections had two important, and partly mutually offsetting effects. On the one hand, they understated the need for fiscal policy to support economic activity. On the other, they overstated the degree of fiscal adjustment associated with the actual set of fiscal policy measures in place-that is, the existing combination of tax rates, expenditure programs, and so on. When the recessions in these countries turned out much more severe than expected, the same set of policies automatically resulted in larger fiscal deficits than originally programmed. The overall implications then depended on how policies were adjusted in response to the changed economic situation: were the policy measures strengthened, were the targets for the deficit revised in the direction of being less ambitious, or was some combination of these responses followed?

${ }^{33}$ The overall costs of banks restructuring were recently estimated at 5 percent of GDP in Malaysia, 13 percent of GDP in Korea, 25 percent in Thailand, and over 50 percent in Indonesia. As a first approximation, only the carrying (interest) costs are included in the fiscal balance, although depending on the circumstances the economic impact may be either larger or smaller (see Lane, 1999). A recent paper (Burnside, Eichenbaum, and Rebelo, 1999) hypothesizes that prospective budget deficits associated with the bailouts of financial institutions were the underlying cause of the Asian currency crisis. 
After it became clear in early 1998 that domestic demand was declining sharply, taking care of the need for current account adjustment, fiscal targets were modified to provide support for economic activity, turning fiscal policy in an expansionary direction. Fiscal deficits were allowed to expand (Figure 12), both through the automatic effects of changing economic conditions-declining economic activity and currency depreciation ${ }^{34}$ as well as, in the case of Indonesia, oil prices--and also through deliberate policy measures. The decomposition of such effects is shown in Table 2.

What effect did this path of fiscal policy have on these economies during this period? Clearly, despite initial intentions, fiscal deficits were allowed to expand. The decomposition presented in Table 2 also suggests that in most cases this expansionary effect went beyond the automatic effects of the economic environment, with policy measures as a whole tending to increase the fiscal deficit. The one exception is Indonesia in both 1997-98 and 1998-99, where policy measures-notably cuts in spending-partially offset the automatic easing resulting from the effects of slower growth and exchange rate depreciation. (This result hinges on the classification as an automatic response of increased spending to maintain some key commodity prices unchanged in the face of currency depreciation.)

There are further questions about the timing of changes in fiscal policy. In particular, did the tighter initial stance of fiscal policy have a negative effect on economic activity that persisted even though the initial tightening was unwound? This question is difficult to answer with available data, since it pertains to the effect of changes in fiscal policy within a given year (which is difficult to disentangle from the pattern of seasonality). But in the case of Indonesia and Korea, it seems prima facie unlikely that the initial fiscal programs had time to have much effect on the economy, both because they were not intended to incorporate a large element of fiscal adjustment and because they were reversed within a very few months. In the case of Thailand, the situation was different: the program was introduced in August 1997 and, at the first quarterly review in November, as early projections suggested underperformance with regard to the initial fiscal targets, additional measures were introduced with a view to achieving the original targets. The latter further tightening of policies - intended at the time to avoid shaking confidence by weakening fiscal targets at the time of accession of a new government-was, in hindsight, mistaken: it delayed the easing of fiscal policy until about six months into the program.

\footnotetext{
${ }^{34}$ In these countries, currency depreciation affected government revenues and expenditures through various channels, including debt service, corporate tax revenues, and-particularly in the case of Indonesia--the cost of providing subsidies on imported goods such as rice.
} 
Figure 12. Indonesia, Korea, Malaysia, Philippines and Thailand : Central Government Balances, 1990-1999

(In percent of GDP)

Indonesia

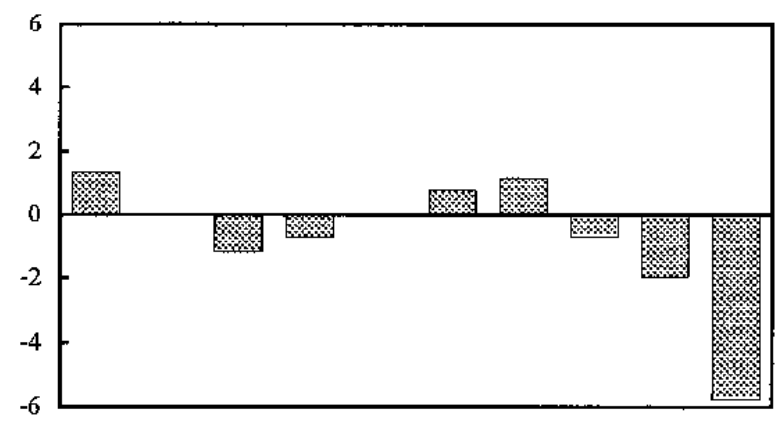

$\begin{array}{llllllllll}1990 & 1991 & 1992 & 1993 & 1994 & 1995 & 1996 & 1997 & 1998 & 1999\end{array}$

Malaysia

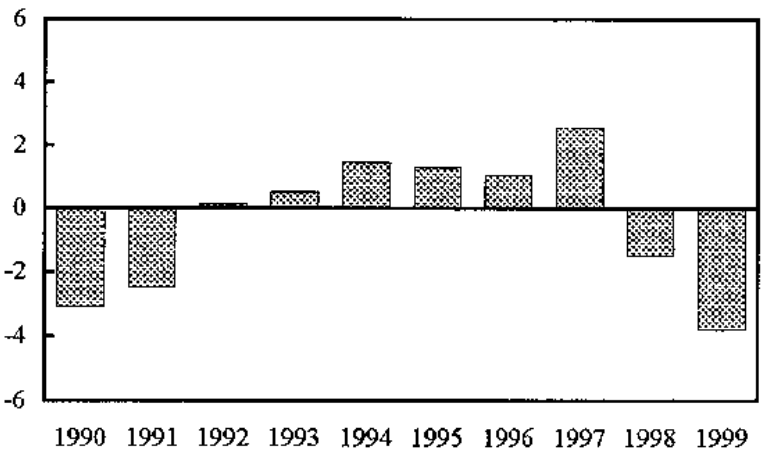

Thailand

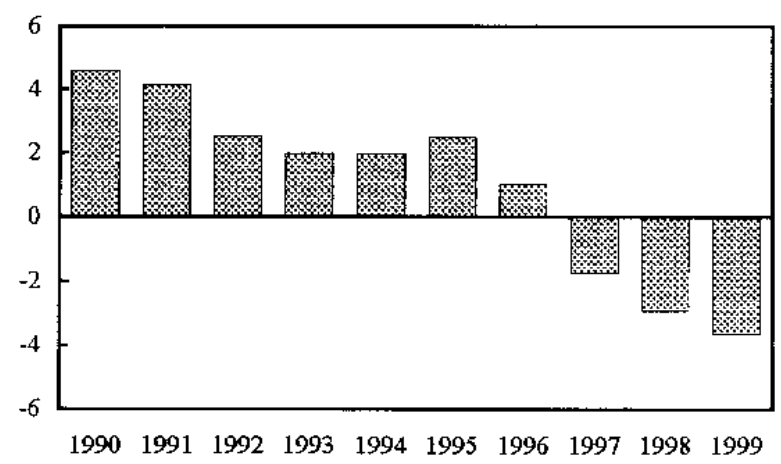

Figures shown are actuals for 1990-1998, and projections for 1999 .

Source: International Monetary Fund, World Economic Outlook
Korea

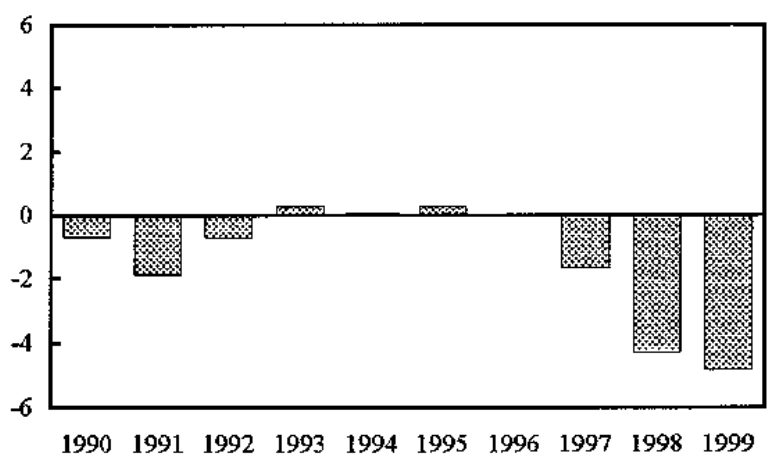

Philippines

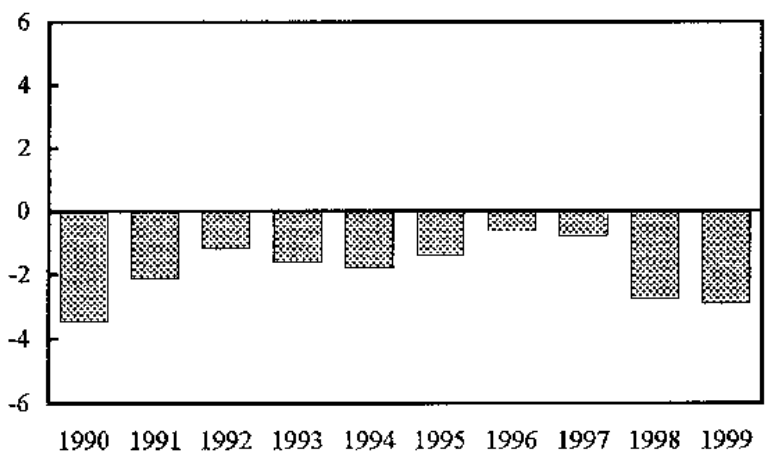


Table 2. Indonesia, Korea, and Thailand: Sources of Changes in the Fiscal Balance, 1997-2000.

(In percent of GDP; a negative number indicates a fiscal deterioration)

\begin{tabular}{|c|c|c|c|c|c|c|c|c|c|c|c|c|c|c|c|c|c|c|}
\hline & \multicolumn{6}{|c|}{ Indonesia // } & \multicolumn{6}{|c|}{ Korea $2 /$} & \multicolumn{6}{|c|}{ Thailand $3 /$} \\
\hline & \multicolumn{2}{|c|}{ Original } & \multicolumn{2}{|c|}{ Intermediate 4/ } & \multicolumn{2}{|c|}{ Latest $5 /$} & \multicolumn{2}{|c|}{ Original } & \multicolumn{2}{|c|}{ Intermediate 4/ } & \multicolumn{2}{|c|}{ Latest 5/ } & \multicolumn{2}{|c|}{ Original } & \multicolumn{2}{|c|}{ Intermediate 4/ } & \multicolumn{2}{|c|}{ Latest S/ } \\
\hline & $1997 / 98$ & $1998 / 99$ & $1997 / 98$ & $1998 / 99$ & $1998 / 99$ & $1999 / 00$ & 1997 & 1998 & 1997 & 1998 & 1998 & 1999 & $1996 / 97$ & $1997 / 98$ & $1996 / 97$ & $1997 / 98$ & $1997 / 98$ & $1998 / 99$ \\
\hline Fiscal balance (level) $6 /$ & 0.3 & 0.5 & -0.9 & -10.1 & $-2,2$ & -6.8 & 0.0 & 0.2 & 0.0 & -5.0 & -3.2 & -5.6 & $-1 . \mathrm{I}$ & -0.1 & -1.6 & -5.1 & -5.1 & -5.3 \\
\hline Changes in fiscal balance & -0.9 & 0.2 & .2 .2 & -9.2 & -1.0 & -4.7 & $\ldots$ & 0.2 & -0.3 & .5 .0 & -3.4 & -2.5 & -3.3 & 1.0 & -4.0 & -3.5 & -3.0 & -0.2 \\
\hline Changes due to economic environment $7 /$ & -1.3 & 0.3 & -4.2 & -11.1 & -3.7 & 2.2 & $\cdots$ & -0.4 & $\ldots$ & -1.9 & -1.6 & -0.4 & -1.1 & -0.9 & -0.3 & -3.1 & -2.8 & 0.6 \\
\hline Policy changes & 0.3 & 0.2 & 2.7 & 1.7 & 2.6 & $-7,4$ & $\ldots$ & -0.1 & $\ldots$ & -2.8 & -2.1 & -1.4 & -1.2 & 1.9 & -2.6 & -0.6 & -0.2 & -0.9 \\
\hline Expenditures & -0.3 & 0.4 & 2.7 & 1.2 & 2.2 & -6.7 & $\ldots$ & -0.9 & $\ldots$ & -4.6 & -3.6 & -1.7 & -1.2 & 0.7 & -2.6 & 0.0 & 0.3 & -0.3 \\
\hline Bank restructuring & -0.5 & 0.0 & 0.0 & -1.6 & -0.4 & -6.9 & $\cdots$ & -0.8 & $\cdots$ & -1.4 & -0.3 & -0.8 & 0.0 & -1.1 & -0.7 & -2.0 & -1.9 & 0.5 \\
\hline Other $8 /$ & 0.2 & 0.4 & 2.7 & 2.8 & 2.6 & 0.2 & $\ldots$ & -0.1 & $\ldots$ & -3.2 & -3.3 & -0.9 & -1.2 & 1.8 & -1.9 & 2.0 & 2.2 & -0.8 \\
\hline Statutory revenue change & 0.6 & -0.2 & 0.0 & 0.5 & 0.4 & -0.7 & $\ldots$ & 0.8 & $\ldots$ & 1.8 & 1.4 & 0.4 & 0.0 & 1.2 & 0.0 & -0.7 & -0.4 & -0.6 \\
\hline Residual (unexplained) & 0.2 & -0.2 & -0.7 & 0.2 & 0.1 & 0.5 & $\ldots$ & 0.7 & $\ldots$ & -0.4 & 0.3 & -0.7 & -1.0 & 0.0 & -1.1 & 0.1 & 0.0 & 0.0 \\
\hline \multicolumn{19}{|l|}{ Memorandum items: } \\
\hline Nominal GDP growth rate & 13.2 & 13.1 & 19.8 & 43.4 & 50.7 & 16.2 & & 6.6 & 7.9 & 0.1 & -0.8 & 4.6 & 10.1 & 11.3 & 6.1 & 5.3 & -0.1 & 2.2 \\
\hline Real GDP growth rate & 5.0 & 3.0 & 4.6 & -12.1 & -15.3 & 1.5 & & 2.5 & 5.5 & -7.0 & -5.8 & 4.5 & 2.5 & 3.5 & -0.4 & -5.0 & -8.8 & 0.0 \\
\hline Public sector debt $9 /$ & .. & .. & .. & .. & 67.7 & 85.8 & & .. & .. & .. & 37.3 & 45.1 & .. & .. & .. & .. & 52.7 & 64.1 \\
\hline Of which: Bank restructuring debt & .. & .. & .. & .. & 15.7 & 46.6 & & .. & .. & .. & 8.9 & 11.9 & .. & .. & .. & .. & 28.7 & 34.4 \\
\hline
\end{tabular}

1/ For Indonesia the first fiscal year considered as "program year" is 1997/98 (April 1997-March 1998)

$2 /$ For Korea, the first fiscal year considered as "program year" is 1998 (January 1998-December 1998).

$3 /$ For Thailand, the first fiscal year considered as "program year" is $1997 / 98$ (October 1997-September 1998)

4i Calculations as of July 1998.

5/ Calculations as of Oetober 1999.

6 This measure of the balance excludes privatization proceeds, but includes bank restructuring costs.

$7 /$ Comprises changes in fiscal position attributable to economic activity, the exchange rate, interest rates, and (in the case of Indonesia) oil prices. For details, see Lane and others, 1999.

8/ Includes outlays for social safety nets and other expenditures

9/ Public sector debt for Indonesia includes central government debt and financial sector restructuring liabilities, exclusive of public enterprise debt; for Korea, it includes debt of central and subnational government and public enterprises and financial sector restructuring liabilities; for Thailand, it includes central government and state enterprise debt, and financial sector restructuring liabilities. 
Later in 1998, another aspect of the story became apparent. Despite the fact that the IMF-supported programs allowed for a significant expansion in fiscal deficits, this expansion did not fully materialize: in all three countries, there was unused room for fiscal expansion under the program targets as revised in mid-year. ${ }^{35}$ This was due in part to the fiscal conservatism of these countries' authorities, and in part to the administrative difficulty of implementing changes in spending and taxation. The result was that fiscal policy turned out less expansionary than envisaged.

\section{STRUCTURAL REFORMS}

A key element of the programs in the Asian crisis countries was a comprehensive structural reform agenda. At its core were measures to deal with the immediate crisis in the financial system and address its underlying weaknesses. They were complemented by measures to facilitate corporate restructuring and strengthen governance, disclosure and accounting standards. In addition, the programs included structural reforms in various other areas, such as trade and capital account liberalization, competition policy, and privatization, which aimed at enhancing the resilience and growth potential of the crisis economies. With the deepening of the crisis and growing social dislocations, the strengthening of social safety nets became a critical issue.

The structural reform components of the Asian programs have been criticized on several counts. It has been argued that the focus on structural issues undermined rather than strengthened market confidence because it reinforced the perception that the crisis had been brought on by fundamental weaknesses in these economies. ${ }^{36}$ This view ignores the fact that structural problems did exist, especially in the financial system and were already recognized by market participants. They became increasingly evident in the months before the crisis broke and played a key role in shifting market sentiment. ${ }^{37}$ Could the programs have been credible if they had failed to deal with these issues? ${ }^{38}$

\footnotetext{
${ }^{35}$ It is interesting that in Malaysia the 1998 budget outturn was also less expansionary than expected.
}

${ }^{36}$ See, for example, Feldstein (1998).

${ }^{37}$ In Thailand, liquidity support to troubled finance companies amounted to almost 7 percent of GDP by June 1997, i.e., before the IMF was asked for assistance; in Korea, weaknesses in the balance sheets of financial institutions were exacerbated by a series of corporate bankruptcies involving several of the country's largest conglomerates, several months prior to the involvement of the Fund.

${ }^{38}$ Research on the evolution and consequences of banking crises suggests that the feedback effects of financial sector weaknesses can have serious consequences for adjustment policies. A Fund study on banking crises concluded that "...correcting of the regulatory framework, central bank operating procedures, and portfolio quality in the financial system are important 
Nevertheless, the question arises whether the reform strategy was appropriate. The point has been made that it was wrong to start restructuring financial institutions and strengthening the regulatory framework in the midst of the crisis. Specifically, it is argued that hasty closure of financial institutions further weakened confidence, while the tightening of regulatory standards worsened the credit crunch. On this view, governments should have sought to buttress confidence through unconditional liquidity support and started dealing with the underlying problems in the financial system once a degree of calm was restored. ${ }^{39}$

Was delaying financial sector restructuring a realistic option? Although we lack a clear counterexample, developments elsewhere in Asia suggest that the answer is no. ${ }^{40}$ In the absence of immediate actions to assess and address the weaknesses in the balance sheets of financial institutions, unconditional liquidity support or comprehensive guarantees would have created enormous moral hazard and likely resulted in a further deterioration. Moreover, extensive liquidity support would have been increasingly difficult to sterilize and would have undermined monetary control; Indonesia in late 1997 is a case in point. ${ }^{41}$ Finally, given that at least the broad dimensions of the problems in the financial system were well known and the failure to act at an early stage had played a key role in the evolution of the crisis, further delays would have raised doubts about governments' resolve to deal with the underlying problems and would have weakened rather than strengthened market confidence at home and abroad. Postponing the start of comprehensive restructuring and reform of the financial system thus would not have provided the hoped-for breathing space to develop and refine reform plans; rather it would have led to a deepening of the crisis.

The financial sector strategies in the Asian programs consisted of three broad strands: emergency measures to stop bank runs, protect the payments system, and limit rapidly accumulating losses; recapitalization of viable institutions and restructuring of those that,

to ensure the effectiveness of adjustment policies." (Sundararajan and Baliño, 1991). And research on "twin crises" suggests that the effects of currency crises tend to be more severe when they are coupled with banking crises. See Kaminsky and Reinhart, 1999.

${ }^{39}$ See for instance Yoshitomi and Ohno, 1999.

${ }^{40}$ Although developments in Japan are not fully comparable to the situation in the Asian crisis countries, they highlight the implications of delaying comprehensive financial sector restructuring.

${ }^{41}$ The extent of liquidity support to financial institutions in the crisis countries varied. Outstanding stocks of central bank credit to banks peaked at 7 percent of GDP in Korea, 17 percent of GDP in Indonesia, and 22 percent of GDP in Thailand. In Korea and Thailand, however, the authorities succeeded in sterilizing the effects of these operations. Liquidity support to financial institutions was also substantial in Malaysia (13 percent of GDP). See Baliño and others, 1999, p.24. 
were insolvent or close to insolvency, and measures to strengthen the regulatory framework. Immediate suspension or closure of clearly non-viable institutions was part of this strategy: it helped contain losses and signaled the authorities' resolve to address the problems in the financial system. (Indeed, in some cases closures had started well before the crisis broke.) However, one of the lessons from the Asian crisis is that for such a step to succeed it must be credible, i.e., cover all institutions that are known to be non-viable, and be accompanied by a temporary introduction of broad based guarantees. ${ }^{42}$ In the case of the closure of 16 small banks at the start of the program in Indonesia, these conditions were not fully met; although the closures were needed, there was a failure to publicize the protection that was provided to depositors; there are also questions as to whether anything short of a blanket guarantee of depositor protection could have stemmed the intensification of bank runs. ${ }^{43}$ In Korea, the bank closures were more credible and bank runs did not pose a serious problem.

Together with other regulatory reforms, the programs envisaged a tightening of loan classification, loss provisioning, and capital adequacy standards. Recapitalization of financial institutions would have held little promise of lasting improvement if it had been done on the basis of existing standards, which generally fell short of international practices. Nevertheless, it was recognized that such changes may have a contractionary effect on lending activity and they were therefore phased in gradually-a process which is not yet complete. ${ }^{44}$

Placing the financial system in the crisis countries on a sound footing has likewise proved to be a protracted process, which is still going on. It has been accompanied by efforts to facilitate corporate restructuring - a task that has proved even more complex. In many

42 These guarantees in turn must also be credible, requiring that public resources be available to honor them.

${ }^{43}$ The guarantee that was in place at the time of closure was limited and not well publicized. (It was later replaced by a blanket guarantee.) In addition, it was widely believed that other non-viable institutions remained in the system. For a more detailed discussion see Baliño and others, 1999.

44 The strategy for introducing tighter regulatory standards varied across countries. In Korea and Thailand, capital adequacy ratios of 8 percent or above were already in place but loan classification and loan loss provisioning standards were relatively lax. In Korea, loan classification rules were tightened in two steps, with the second change expected to become effective by end 1999; in Thailand the implementation of stricter loan classification and provisioning rules began in mid 1998 and will be completed by end 2000. In Indonesia, loan classification and provisioning rules were tightened in October 1998; at the same time, capital adequacy requirements were temporarily lowered to cushion the impact of these changes. For a detailed description of the reform strategies pursued in individual countries see Baliño and others, 1999. 
instances, the institutional and legal framework was inadequate and had to be improved before progress could be made. ${ }^{45}$

Financial and corporate restructuring have been by far the most important areas of structural reform in the Asian crisis countries, particularly in Korea and Thailand. ${ }^{46}$ Given the enormous challenges in these areas, the question arises whether the programs could reasonably be expected to deal in addition with structural problems in other areas. There is no simple answer to this question. For one, many of these measures were important for the success of the programs, even in the short run. In Korea, for example, adjustment in the corporate sector required reforms in the labor market. In Indonesia, the dislocations brought about by the deepening crisis focussed attention on basic issues such as the restoration of the rice distribution system. In all countries, measures to strengthen the social safety nets and alleviate the impact of the crisis on the poorest segments of society were critical for the sustainability of the programs. Nevertheless, in retrospect it is arguable whether all measures included in the broad structural reform agendas were as important as these. The need for greater prioritization may be another lesson from the Asian programs.

\section{LESSONS}

This paper has examined a variety of aspects of the policy response to the crisis in East Asia, discussing both the overall strategy and the ways that strategy was implemented. This experience suggests a number of lessons that may be relevant in addressing the crises that will, inevitably, occur in the future.

The most general question is whether the overall strategy for responding to the crisis in the context of IMF-supported programs was appropriate. This strategy contained three mutually reinforcing elements-financing, macroeconomic policy adjustment, and structural reform-which together were intended to restore confidence and set the economies affected back on the path of stability and sustainable growth.

This overall strategy needs to be evaluated in relation to the alternatives. At one extreme, one could envisage a strategy involving much larger financing (both official and private) to restore confidence, while orienting policies toward cushioning the economy against possible adverse effects on growth. At the same time, structural reforms would be delayed to avoid compounding the strains of the crisis. At the other extreme, one could

${ }^{45}$ In Thailand, for example, important amendments to the bankruptcy law and foreclosure procedures were enacted only in early 1999.

${ }^{46}$ In Korea, close to 90 percent of well over 100 structural reform measures implemented from December 1997 to January 1999 dealt with financial and corporate restructuring and related issues such as regulatory and accounting standards, corporate governance, as well as supporting legal reforms. 
imagine eliminating official financing, letting the authorities work out the problem with private creditors. This would at least have the effect of minimizing moral hazard.

Both of these alternatives have significant drawbacks. The first strategy, by postponing or phasing more gradually the needed macroeconomic and structural policies, could compound the situation, placing an even larger burden on policies later on. This would not necessarily be a problem if the crisis were purely a liquidity crisis driven by self fulfilling expectations which could be reversed through the provision of finance, but this was not the case in any of the Asian crisis countries: instead, mounting financial sector problems, which in the case of Thailand were accompanied by significant macroeconomic imbalances, were well-known and clearly evident before the crisis, and rapidly worsened with the exchangerate movements of the early phase of the crisis itself. Providing additional financing without making a credible start in tackling the underlying problems would only have made these problems worse. The financial policies of Japan in the earlier 1990s-where failure to acknowledge and address financial sector weaknesses sufficiently forcefully contributed to a slump lasting many years-were found wanting: better to move ahead in addressing these weaknesses and set the stage for a resumption of growth, as we now see emerging in the crisis countries. One could perhaps have been more selective in choosing which reforms to push ahead and which ones to postpone-indeed, lessons in that regard are discussed below-but the key principle is that some substantial core of macroeconomic policies and structural reforms needed to be an integral part of the policy response.

The other main difficulty with this alternative strategy of larger financing and delayed adjustment is that it would require either much larger official resources or substantial bail-ins of private creditors. Regarding the former, official financing would need to be much larger than in existing programs. However, even in programs with exceptional access-such as in the case of Korea--the money available in the first quarter of the program was less than a third of the amount needed to cover outstanding short-term debt. ${ }^{4}$ Moreover, the money that can exit if policies are perceived as unsustainable is not limited to outstanding short-term debt: rather, given the potential for domestic capital flight and speculation, a virtually bottomless pool of money would be needed. The money was simply not available for such large official financing - and it is unlikely that the pool of financing available in cases of crises could be expanded to several times its present size. And even if official financing could be made available on such a scale, this would make moral hazard a much more relevant issue. Regarding the latter alternative-bailing in private creditors - this was done, but at different times, in all three countries, and it is fair to ask whether in Indonesia and Korea it could have been done earlier; accordingly, there has been much more attention recently to finding more effective ways of keeping private creditors involved. But there are limits to the extent to which such measures would be useful in closing financing gaps-

\footnotetext{
${ }^{47}$ This comparison is of course only illustrative; a much more sophisticated set of calculations would be needed to determine the amount of financing that should be provided under hypothetical conditions.
} 
especially because, if bail-ins become the norm rather than the exception, one should expect that private investors will become nimbler in getting their money out in time.

The other alternative strategy, refraining from any kind of official financing to deal with crises, while it would perhaps minimize moral hazard, would not necessarily maximize global prosperity-just as banning auto insurance might encourage safe driving but would not necessarily be welfare-enhancing. Although shutting off official lending in such cases might have some impact in encouraging more prudent policies by governments and better risk management by private investors, it could only do so by making those crises that do occur more damaging to borrowers and lenders alike-as well as to the unfortunate residents of the countries affected. Moreover, countries facing crises without international support could well respond with policies that impose negative externalities on their neighbors: providing an alternative to such "measures destructive of international prosperity" was one of the main reasons that the IMF was originally established.

Thus, we would argue that there is no good alternative to a strategy of crisis management that combines official financing with policy adjustment. At the same time, many of the details of this strategy are subject to discussion and some important lessons for future practice emerge in several areas.

To begin with, there are some further lessons for the scale and composition of program financing. With regard to official financing, a major lesson-which emerges in particular from the case of Korea--is that there are limits to the extent to which policy adjustment can substitute for financing when the situation is permitted to deteriorate to the extent it did before the Fund was called in in late November 1997. When maturing foreigncurrency-denominated short-term debt is far in excess of usable net international reserves plus credibly committed official financing, the iron logic of a funding crisis takes hold, and there is little that policy adjustments can do to reverse the situation in a few weeks before the money runs out. If the situation is permitted to deteriorate to this extent-and in that itself there is an important lesson-there needs to be large official financing or an effective bail-in of private creditors or some combination of the two; the only alternative is default, the effects of which are extremely uncertain and may well be extremely adverse. It may be the case that contagion is the trigger for the crisis, but it is the imbalance between new resources and maturing obligations that makes that contagion so powerful.

This lesson also suggests a continuing need to explore the scope for private creditor involvement. Work in this area over the past year and a half has uncovered some useful tools, but also illustrated their limitations. The experience with a number of recent cases where private creditors have been required to take up some of the financing burden ${ }^{48}$ has also illustrated many complexities, especially when a variety of different financial instruments,

\footnotetext{
${ }^{48}$ These countries include Ecuador, Pakistan, Romania, Russia, and Ukraine, all of which face very different macroeconomic and structural problems than the Asian crisis countries.
} 
including bonds, are involved. Important issues remain regarding whether and how bail-ins of private creditors should be incorporated more systematically into Fund-supported programs.

A related issue is the usefulness of capital controls to stem outflows during a crisis. Unfortunately (for the state of our knowledge), this approach was really never tried during the East Asian crisis: Malaysia's controls were introduced, not at the outbreak of the crisis, but after capital outflows had abated; it is thus perhaps not surprising that Malaysia's experience was rather similar to that of other countries in the region.

Increasingly, it has been realized that there is no good way to deal with the consequences of a capital account crisis - only more or less bad ways. Increasing attention has therefore turned to the need for prevention: it is far better to stem the buildup of vulnerabilities underlying such a crisis than to deal with the consequences of a crises when they occur. Prevention includes some elements that are widely agreed: sound macroeconomic policies; well-focused financial supervision and regulation; and transparency, which helps market discipline to work more effectively so that information is priced into the market in normal times rather than coming as a nasty surprise during a crisis. The experience of the crises has also underscored the difficulty of maintaining "fixed but adjustable" exchange rates under high capital mobility, suggesting that the extremes-a free float or a "hard" peg via a currency board-are less prone to attack. Another possible element of prevention, Chilean-style controls on capital inflows, is more controversial, but there is now increasing support for the view that they may be a useful tool, especially in countries that are in the process of bringing their financial supervision and regulation up to international standards.

There are also lessons regarding the macroeconomic and structural policies introduced during the crisis. On the structural side, the need to concentrate on the core of financial and corporate sector reforms is becoming increasingly apparent. This lesson is underscored by the uneven progress of these countries in implementing reforms in this area. While bank restructuring has generally progressed well, there has been much more less success with the corporate restructuring that is needed to make this financial restructuring durable. As they emerge from the market turmoil and macroeconomic slump associated with the crisis, the countries in the region face a large unfinished agenda in this area, as well as for structural reforms more generally. It is necessary to take account of the time required to implement effective reforms in this area-which often need to include ancillary reforms in related areas such as bankruptcy law and labor regulations - and also the need to make a credible and early start down this road. Again prevention is surely the best route.

With regard to monetary policy, the experience of different countries shows a diversity of experience. In Korea and Thailand policies were tightened, after some initial hesitation, together with other action; market confidence recovered; and policies were eased again as their currencies recovered in value. In Indonesia, policies were not tightened in an economically meaningful sense for quite some time: money and credit continued to expand rapidly well into 1998 , inflation accelerated, as the rupiah plunged, and high nominal interest rates corresponded to well-founded expectations of rapid currency depreciation. There have 
been reports of credit market disruptions in all three countries, but none of the recent studies of this phenomenon have provided convincing evidence of credit crunches driven by monetary tightening and tightened capital adequacy standards ${ }^{49}$ rather than a reflection of the heightened perception of riskiness and destruction of collateral associated with the balancesheet effects of the crisis itself. Moreover, the view that there was a general collapse of money and credit is not consistent with the facts, in any of these countries.

Another issue that has been much discussed is whether monetary tightening may actually have had a perverse effect, worsening the currency depreciation. The identification problem-given that market expectations trigger both exchange rate movements and interest rate responses - has frustrated systematic testing of this phenomenon, and anecdotal evidence is also misleading: it is not surprising that there are some episodes during which currencies depreciated while interest rates increased. The conclusion is that, while logically there must be some level of interest rates beyond which further increases are counterproductive (and eventually irrelevant, since ultimately no transactions would take place at those rates), there is still no convincing reason to believe that this level was reached during the East Asian crisis.

With regard to fiscal policy, the main lesson that emerges is the need for flexibility in response to changing information on the macroeconomic situation. The main problem with fiscal policy in the Asian crisis countries was that fiscal policy was predicated on an incorrect view of the macroeconomic situation; once evidence accumulated that private domestic demand was already being sharply curtailed, this changed the nature of the fiscal adjustment needed and called for a reversal of the direction of policy. However, the experience has also provided a reminder that fiscal policy is not a flexible instrument of economic control; this was highlighted by the difficulty of implementing a fiscal stimulus when, in mid-1998, there was unused room for fiscal expansion in the IMF-supported programs in Indonesia and Korea.

The IMF's initial failure-along with that of most other observers-to predict the macroeconomic developments associated with the crisis has been the subject of a great deal of attention. When this failure is examined in a broader context, it appears that this is part of a larger problem. It is not the case that all, or even a majority of Fund program projections of economic growth tend to err on the high side. Rather, the problem appears to be that wethat is, the Fund staff, but probably also the profession at large - tend to be weak at forecasting macroeconomic developments in the face of volatile capital movements: Fund program projections have a large upward bias for a subset of countries with large exposure to capital movements (as reflected also in comparatively high access to the Fund's resources).

${ }^{49}$ Moreover, the phasing in of these regulatory standards, as discussed in section 7 , falsifies the picture of a sudden raising of the bar that is sometimes portrayed; in many cases, higher capital adequacy standards were softened considerably by a more gradual phasing in of international standards of loan classification and provisioning standards. 
In the case of the Asian crisis, this reflects large errors in forecasting market reactions via exchange rates and capital movements - which in turn forced much larger current account adjustments than expected via balance sheet effects that were also not fully foreseen. This suggests a need for further modeling and empirical work on macroeconomic developments during capital account crises.

Finally, the experience shows that managing a capital account crisis is an inherently much messier and more protracted process than a conventional balance of payments crisis. With an old-style crisis, addressing the crisis and restoring confidence depends mainly on making needed adjustments to monetary and fiscal policy; although such adjustments may be painful, they are comparatively straightforward to assess and monitor, and once the package is in place and credible steps have been taken to implement it, market confidence may be restored. In contrast, in a situation like the Asian crisis, which stemmed mainly from underlying weaknesses in financial systems, and was then aggravated by dynamically unstable processes flowing from those weaknesses, many of the steps needed to address the crisis-such as addressing failed financial institutions, restructuring corporate debt, and reforming legal procedures for dealing with bankruptcy-are inherently time-consuming and depend on the authorities' commitment and capacity to implement them. It is therefore much more difficult to convince markets and the public that the right steps are indeed being taken and are having an effect. This makes the resolution of such a crisis an inherently more convoluted and protracted process, and it may be unrealistic to hope that confidence can be restored very quickly. The main lesson, again, is prevention: best to implement sound macroeconomic and prudential policies to limit vulnerabilities beforehand, since there is no known way of taking away all the pain from a serious financial crisis. 


\section{References}

Adams, Charles, Donald J. Mathieson, Garry Schinasi, and Bankim Chadha, 1998, International Capital Markets: Developments, Prospects, and Key Policy Issues, World Economic and Financial Surveys (Washington: International Monetary Fund).

Adams, Charles, Donald J. Mathieson and Garry Schinasi, 1999, International Capital Markets: Developments, Prospects, and Key Policy Issues, World Economic and Financial Surveys (Washington: International Monetary Fund).

Baliño, Thomas, Charles Enoch, Anne-Marie Gulde, Mark Quintyn, and Leslie E. Teo, 1999, Financial Sector Crisis and Restructuring-Lessons from Asia, Preliminary version (Washington: International Monetary Fund).

Basurto, Gabriela, and Atish Ghosh, 2000, "The Interest Rate-Exchange Rate Nexus in the Asian Crisis Countries?" IMF Working Paper No. WP/00/19 (Washington: International Monetary Fund).

Bong-Chan Kho and Rene M. Stulz, 1999, "Banks, the IMF, and the Asian Crisis" unpublished draft.

Burnside, Craig, Martin Eichenbaum, and Sergio Rebelo, 1999, "Prospective Deficits and the Asian Currency Crisis," Policy Research Working Paper 2174 (Washington: World Bank).

Calamoris, Charles, 1998, "The IMF's Imprudent Role as Lender of Last Resort," The Cato Journal, Vol. 17, No. 3.

Claessens, Stijn, Simeon Djankov, and Giovanni Ferri, 1998, "Corporate Distress in East Asia: Assessing the Impact of Interest and Exchange Rate Shocks" (unpublished; Washington: World Bank).

Corsetti, Giancarlo, Paolo Presenti, and Nouriel Roubini, 1998, "What Caused the Asian Currency and Financial Crisis? Parts 1 and 2," NBER Working Papers Nos. 6833 and 6834 (December).

Dollar, David and Mary Hallward-Driemeier, 1998, "Crisis, Adjustment, and Reform in Thai Industry," (unpublished; Washington: World Bank).

Domaç, Ilker, and Giovanni Ferri, 1998, "The Real Impact of Financial Shocks: Evidence from Korea," Policy Research Working Paper 2010, November (Washington: World Bank).

Eichengreen, Barry J., 1999, Toward a New Financial Architecture: A Practical Post-Asia Agenda (Washington: Institute for International Economics). 
Feldstein, Martin, 1998, "Refocusing the IMF," Foreign Affairs 77, No. 2 (March/April).

Friedman, Milton, and Anna J. Schwartz, 1963, A Monetary History of the United States, 1867-1960 (Princeton NJ: Princeton University Press).

Furman, Jason and Joseph E. Stiglitz, 1998, "Economic Crises: Evidence and Insights from East Asia," Brookings Paper on Economic Activity, 2:1-135.

Ghosh, Swati R., and Atish R. Ghosh, 1999, "East Asia in the Aftermath: Was There a Crunch?" IMF Working Paper No. 99/38 (Washington: International Monetary Fund).

Goldfajn, Ilan, and Poonan Gupta, 1999, "Does Monetary Policy Stabilize the Exchange Rate Following a Currency Crisis?" IMF Working Paper 99/42, March 1999 (Washington: International Monetary Fund).

Goldfajn, Ilan, and Taimur Baig, 1998, "Monetary Policy in the Aftermath of Currency Crises: The Case of Asia", IMF Working Paper 98/170, (Washington: International Monetary Fund).

Gould, David M., and Steven B. Kamin, 1999, "The Impact of Monetary Policy on Exchange Rates During Financial Crises, " paper presented at the Pacific Basin Conference on Financial Crises in Emerging Markets, San Francisco, September.

Gray, Dale F., 1999, "Assessment of Corporate Sector Value and Vulnerability: Links to Exchange Rate and Financial Crises," Technical Paper, (Washington: World Bank).

Guitián, Manuel, 1981, Fund Conditionality: Evolution of Principles and Practices, IMF Pamphlet Series No. 38, (Washington: International Monetary Fund).

International Monetary Fund, 1999, "Involving the Private Sector in Forestalling and Resolving Financial Crises-Additional Considerations," (Washington).

International Monetary Fund, 1997, World Economic Outlook, December 1997: A Survey by the Staff of the International Monetary Fund, World Economic and Financial Surveys (Washington).

International Monetary Fund, 1998, World Economic Outlook, April 1998: A Survey by the Staff of the International Monetary Fund, World Economic and Financial Surveys (Washington).

Jeanne, Oliver, and Charles Wyplosz, 1999, "The International Lender of Last Resort: How Large is Large Enough?" (draft; Washington: International Monetary Fund). 
Kaminsky, Graciela L., and Carmen Reinhart, 1999, "The Twin Crises: The Causes of Banking and Balance of Payments Problems," The American Economic Review, Vol. 89 (June), p.473.

Kraay, Aardt, 1998, "Do High Interest Rates Defend Currencies During Speculative Attacks?" (unpublished; Washington: World Bank).

Krugman, Paul, 1999, "Balance Sheets, the Transfer Problem, and Financial Crises." (Paper prepared for Festschrift volume in honor of Robert Flood.)

Lane, Timothy, 1999, "The First Round Monetary and Fiscal Impact of Bank Recapitalization in Transition Economies," International Economic Policy Review, Volume 1, edited by Paul Masson, Padma Gotur, and Timothy Lane (Washington: International Monetary Fund).

Lane, Timothy, and Steven Phillips, 1999, "Does IMF Financing Create Moral Hazard?," (Forthcoming; Washington: International Monetary Fund ).

Lane, Timothy, Marianne Schulze-Ghattas, Steven Phillips, Atish Ghosh, Javier Hamann, and Tsidi Tsikata, 1999, IMF-Supported Programs in Indonesia, Korea, and Thailand: A Preliminary Assessment, Occasional Paper 178 (Washington: International Monetary Fund).

Lebergott, Stanley, 1984, The Americans: An Economic Record (New York: W.W. Norton).

McKinnon, Ronald I., 1999, "The East Asian Dollar Standard, Life After Death?" (Paper presented at Seminar on The East Asian Crisis: Lessons for Today and for Tomorrow, Siena, Italy, May).

Meltzer, Allan, 1998, "Asian Problems and the IMF," The Cato Journal, Vol. 17, No. 3.

Musso, Alberto, and Steven Phillips, 1999, "IMF-Supported Programs: The Relationship Between Projections and Outcomes" (forthcoming; Washington: International Monetary Fund).

Nunnenkamp, Peter, 1999, "The Moral Hazard of IMF Lending: Making a Fuss about a Minor Problem?" Kiel Discussion Papers No. 332.

Radelet, Steven, and Jeffrey D. Sachs, 1998, "The East Asian Financial Crisis: Diagnosis, Remedies, Prospects," Brookings Papers on Economic Activity: 1, pp.1-90.

Radelet, Steven and Jeffrey Sachs, 1999, "What Have we Learned, So Far, from the Asian Financial Crisis?" (draft; January). 
Rogoff, Kenneth, 1999, "International Institutions for Reducing Global Financial Instability," Journal of Economic Perspectives 13 (Fall).

Sargent, Thomas J. and Neil Wallace, 1981, "Some Unpleasant Monetarist Arithmetic," Federal Reserve Bank of Minneapolis Quarterly Review 5, No. 3,(Fall) pp.1-17.

Sundararajan, V. and Thomas J.T. Baliño, 1991, "Issues in Recent Banking Crises," in Banking Crises: Cases and Issues (edited by V. Sundararajan and Thomas J. T. Baliño ) (Washington: International Monetary Fund).

Tanner, Evan, 1999, "Exchange Market Pressure and Monetary Policy: Asia and Latin America in the 1990s," IMF Working Paper 99/114 (Washington: International Monetary Fund).

Vásquez, Ian, 1998, "Why the IMF Should Not Intervene," Summary of comments presented at conference on The Asian Crisis and the Reform of the Monetary System, February.

Vines, David, and Jenny Corbett, 1999, "Asian Currency and Financial Crises: Lessons from Vulnerability, Crisis, and Collapse," World Economy 22 (March) pp. 155-177.

Willett, Thomas D., 1999, "Did the Mexican Bailout Really Cause the Asian Crisis?" Claremont Policy Briefs, Issue No. 99-01 (The Claremont Institute for Economic Policy Studies, The Commons Institute for International Economic Studies, and The Lowe Institute of Political Economy).

World Bank, 1999, Global Economic Prospects and the Developing Countries 2000, (Washington: World Bank).

World Bank, 1998, East Asia: The Road to Recovery, (Washington: World Bank).

Yoshitomi, Masaru and Kenichi Ohno, 1999, "Capital-Account Crisis and Credit Contraction: A New Nature of Crisis Requires New Policy Papers," ADBI Working Paper 2 (Tokyo: Asian Development Bank Institute).

Zettelmeyer, Jeronimo, 1999, "The Case Against Partial Bail-outs," (draft, Washington, International Monetary Fund). 